\title{
Household Debt, Macroprudential Rules, and Monetary Policy
}

\author{
Nurlan Turdaliev (University of Windsor) \\ Yahong Zhang (University of Windsor)
}

Working paper 17 - 04

Working papers are in draft form. This working paper is distributed for purposes of comment and discussion only. It may not be reproduced without permission of the copyright holder. Copies of working papers are available from the author or at http://ideas.repec.org/s/wis/wpaper.html. 


\title{
Household Debt, Macroprudential Rules, and Monetary Policy
}

\author{
Nurlan Turdaliev*i $\quad$ Yahong Zhang ${ }^{*}$
}

May 2, 2017

\begin{abstract}
Today's Canadian economy features a historic high of household debt and persistently low growth rate. The average debt-to-GDP ratio has reached the level experienced in the U.S. just prior to the recent financial crisis. Should monetary policy lean against the household indebtedness or are macroprudential policies better suited for the task? To provide a quantitative answer, this paper develops a small open economy dynamic stochastic general equilibrium model featuring a banking sector that channels funds between household savers and borrowers. We estimate the model using the Canadian data from 1991Q1 to 2015Q3 and conduct policy experiments. We find that using monetary policy that reacts to household indebtedness increases inflation volatility and lowers borrowers' welfare, while using macroprudential policies such as lowering the loan-to-value ratio limit increases borrowers' welfare.
\end{abstract}

JEL: classification: E32;E44; E52

Keywords: household debt, macroprudential rules, monetary policy

*We thank the participants at the 2016 Canadian Economic Association Meeting and the Brown-bag seminar at the University of Windsor for their helpful comments and suggestions. All errors are our own.

${ }^{\dagger}$ Department of Economics, University of Windsor, Windsor, Ontario, Canada N9B 3P4; Email: nurlan@uwindsor.ca

${ }^{\ddagger}$ Department of Economics, University of Windsor, Windsor, Ontario, Canada N9B 3P4; E-mail: yzhang@uwindsor.ca. 


\section{Introduction}

Today's Canadian economy features a historic high of household debt and persistently low growth rate. The average debt-to-GDP ratio from 1991Q1 to 2009Q1 is 0.64 and average GDP growth rate 1.24 per cent; and the corresponding numbers for the period from 2009Q2 to 2015Q3 are 0.93 and 1.16 per cent. Due to the low growth rate following the onset of the recent financial crisis, monetary policy has been accommodative: since 2009, the policy rate has been either at one per cent or lower. This accommodative monetary policy aiming to stimulate the economy has an undesirable outcome: it encourages households to take out more debt, resulting in the Canadian debt-to-GDP ratio climbing up and reaching the high levels experienced in the U.S. in the period just prior to the financial crisis (Figure 1). A high level of indebtedness may render the economy more vulnerable to negative shocks than otherwise. For example, it is well documented that in the U.S. during the financial crisis the households that took subprime loans were much more prone to foreclosure and bankruptcy (Li and White, 2009). Those households were highly leveraged and when the housing market collapsed, it became very difficult for them to refinance their mortgages, and many of them struggled to keep up with paying their monthly mortgage payments.

Figure 1: Debt to GDP Ratio: Canada Versus US

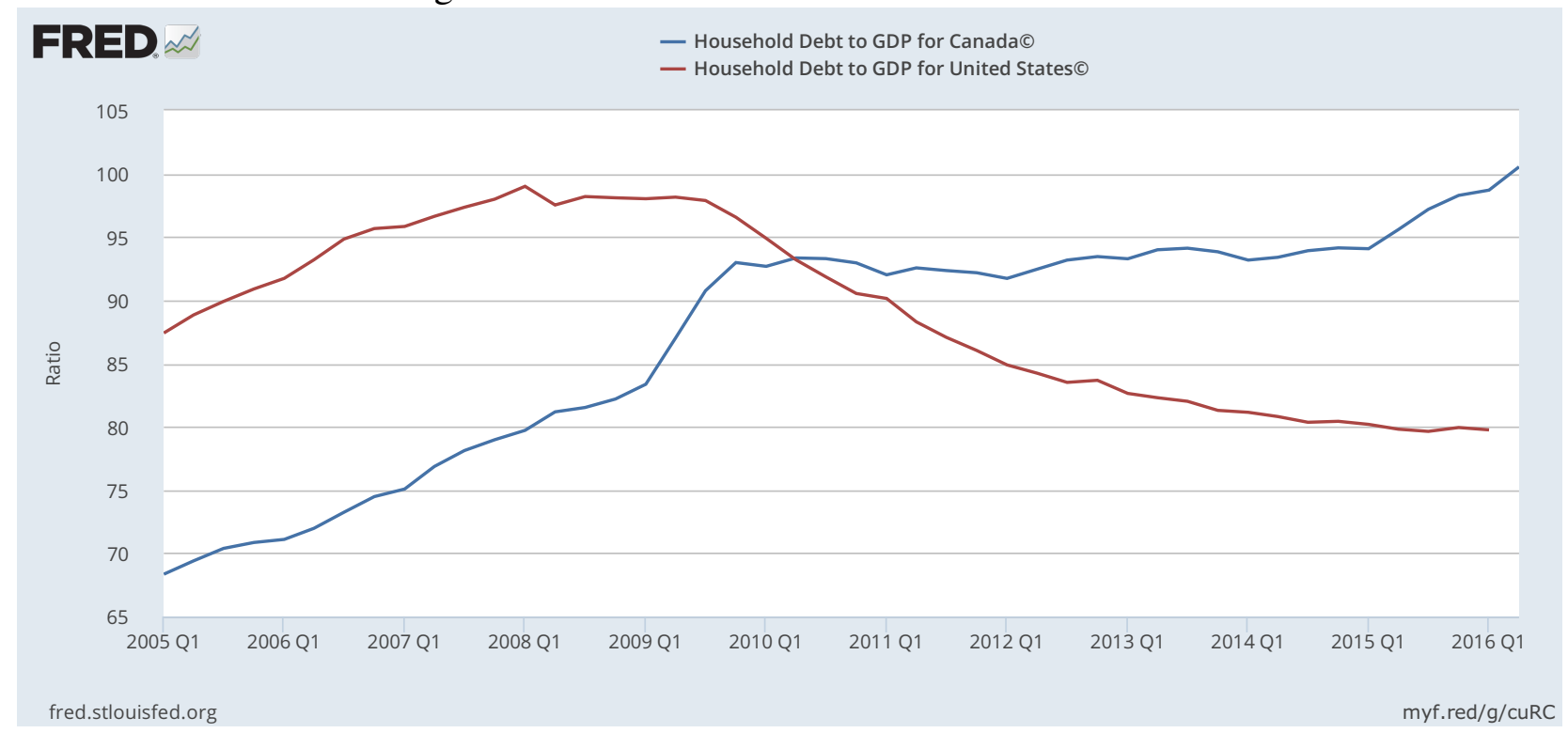

To the policy makers in Canada, the alarmingly high level of household indebtedness is a call for policy action. It is not clear, however, what the best tool to reduce household debt is. A growing literature on the interaction of monetary and macroprudential policy centers on this question: Should monetary policy "lean" against an imbalance in the housing market? In other words, should the policy rate be used as the main tool to reduce household indebtedness or are macroprudential tools (such as control of the loan-to-value ratio) better suited for the task?

To provide a quantitative answer to the above question, in this paper we build a small open economy dynamic stochastic general equilibrium (DSGE) model featuring two types of households 
with heterogeneous preferences over saving and borrowing (Iacoviello, 2005). It also features a banking sector in which financial frictions are explicitly modeled (Gertler and Karadi, 2011). A banking sector "financial accelerator" arises in the model due to these frictions, and it amplifies the household debt response to shocks such as an accommodating monetary policy shock or a positive housing demand shock. In view of the openness of the Canadian economy, the model exhibits both domestic and foreign shocks. We estimate the model using the Canadian data from 1991Q1 to 2015Q3 and identify the main shocks driving the fluctuations in Canadian household debt.

Further, based on the estimates, we conduct the following experiments: 1) We consider two economies with different levels of indebtedness and compare welfare gains/losses for borrowers and savers when these two economies are subjected to the estimated shocks. 2) We allow the policy rate to react to house price inflation in addition to CPI inflation and the output gap (augmented monetary policy), and compare welfare of both borrowers and savers in our baseline model (in which monetary policy only reacts to inflation and the output gap) and the alternative regime. 3) We simulate the economy to quantify the welfare gains/losses associated with the recent loan-to-value (LTV) regulation changes in Canada between 2008 and 2012.

Our main results are as follows. First, we find that the household debt fluctuations in the Canadian economy are mainly driven by housing demand and banking sector shocks. The comparison between the model with a banking sector and the one without it shows that the financial frictions in the banking sector act as a "financial accelerator", which amplifies the effect of the shocks hitting the economy. Second, we show that highly leveraged borrowers are more vulnerable when they face negative shocks: in response to a contractionary monetary policy shock, the reduction in consumption of the borrowers with a high level of indebtedness is much larger than that of the borrowers with low indebtedness. Overall, borrowers are better off when their leverage is lower.

Third, we find that compared to the baseline case, inflation is much more volatile and borrowers' welfare lower under the augmented monetary regime. This is mainly due to the responses of the economy to disturbances such as housing demand shocks. The recent literature has emphasized the collateral effect: a rise in housing prices leads to a rise in household consumption. However, we demonstrate that the strength of the collateral effect depends on the type of the shocks. In response to an expansionary monetary policy shock, both housing prices and consumption rise due to the strong presence of the collateral effect; on the other hand, housing prices and household debt rise and consumption declines when reacting to a housing demand shock. This is because the demand for houses crowds out the demand for consumption goods and the collateral effect is not as strong as in the monetary policy shock case. We find that due to the weaker collateral effect, a positive housing demand shock leads to a rise in household debt and a decline in aggregate consumption, causing inflation to decline. ${ }^{1}$ Thus, under the augmented monetary policy regime, a policy rate increase in response to housing price inflation will depress investment and output, pushing inflation

\footnotetext{
${ }^{1}$ Note that this is in line with what is observed in the recent Canadian data from 2011Q1-2015Q3: house prices and inflation are negatively correlated (-0.35).
} 
further down and leading to an even larger reduction in consumption for the borrowers.

Lastly, we find that macroprudential policy similar to that adopted in Canada between 2008 to 2012 can improve welfare of the borrowers. During those four years, the Canadian government had implemented several regulation changes regarding LTV in the mortgage lending market, including lowering the maximum LTV ratio for new mortgages from 100 per cent to 95 per cent and the maximum LTV ratio for mortgage refinancing and mortgages for investment properties from 95 per cent to 80 per cent. We show that the reduction in LTV limits improves borrowers' welfare.

This paper is related to the following three strands of literature. The first explores the role of financial intermediation in business cycle fluctuations (Gertler and Karadi, 2011; Gertler and Kiyotaki, 2015; Meh and Moran, 2010; Gerali et al., 2010; Zhang, 2015; Iacoviello, 2015). Our paper is particularly related to Zhang (2015) where a micro-founded banking sector (Gertler and Karadi, 2011; Gertler and Kiyotaki, 2015) is introduced to a DSGE model with household debt, and the model is estimated using the U.S. data. The banking sector features a friction in the form of moral hazard (bankers are tempted to divert funds from banks) that leads to an incentive constraint facing bankers. There is a threshold level of deposits beyond which the bank would have the incentive to default. The patient households will choose not to expand their deposits beyond this threshold, and as a result there is an interest rate spread between the lending and borrowing rates in the model. Zhang (2015) shows that due to the financial frictions in the banking sector, borrowers face a mortgage risk premium. It also shows that there exists a "banking sector financial accelerator", amplifying the household debt response to certain shocks.

The second strand studies household debt and business cycle (Neri and Iacoviello, 2010; Iacoviello, 2005; Christensen et al., 2016). Following Kiyotaki and Moore (1997), Iacoviello (2005) develops a model with two types of households that features borrowing and lending between them. He introduces collateral constraints tied to real estate values. Using a borrower-lender setup developed by Iacoviello (2005), Christensen et al. (2016) demonstrate the importance of collateral constraints in their model of the Canadian economy. They estimate the model using the Canadian data and show that the version of the model with collateral constraints outperforms the one without them.

And the third strand of the literature explores the effect of macroprudential policy on macroeconomic aggregates and how the interaction between monetary and macroprudential policy may reduce household indebtedness. Some of the recent works include Alpanda and Zubairy (2017), Bruneau et al. (2016), Chen and Columba (2016), and Alpanda and Ueberfeldt (2016). Alpanda and Zubairy (2017) study implications of various housing-related tax policies and regulatory loanto-value changes on reducing household indebtedness; Chen and Columba (2016) build a model of Sweden based on Gerali et al. (2010) and demonstrate that demand-side macroprudential measures such as LTV ratios and amortization requirements are more effective in curbing household debt than monetary policy. Both Bruneau et al. (2016) and Alpanda and Ueberfeldt (2016) focus on the Canadian economy. Alpanda and Ueberfeldt (2016) use a small-scale regime-switching model 
to evaluate the welfare gains/losses if monetary policy "leans" against the deviation of credit from trend, while Bruneau et al. (2016) introduce a news shock and compare the option of introducing a countercyclical loan-to-value ratio with that of a monetary policy rule augmented with house price inflation.

Our paper links the three strands of literature together. In particular, our paper connects the first two literatures by embedding a frictional banking sector in a small open economy model with a typical Iacoviello (2005)-type setup. We then conduct our policy experiments in an environment where the banking sector plays an active role in the household debt dynamics.

The remaining of the paper is organized as follows. In Section 2, we present the model. Section 3 describes the data and estimation. We analyze the model's performance in Section 4 and conduct policy experiments in Section 5. In Section 6, we offer some concluding remarks.

\section{The Model}

Consider a discrete time, infinite horizon economy populated by five types of agents: households, house producers, goods producers, financial intermediaries and a government. Their optimization problems and the market clearing conditions are presented below.

\subsection{Households}

There is a measure one of infinitely lived households. There are two types of them, patient and impatient; they differ only by the rate at which they discount the future. Patient households are denoted $p$ and represent a share $a$ of the population. Impatient households are denoted $i p$ and represent a share $1-a$ of the population. The discount factors for the patient and impatient households are $\beta_{p}$ and $\beta_{i p}$ respectively, with $\beta_{p}>\beta_{i p}$. In the model, because the impatient households discount the future more, they are the borrowers, and the patient households are the lenders (savers). The financial intermediaries channel the funds from lenders to borrowers.

\subsubsection{Patient households' problem}

A patient household maximizes

$$
E_{0} \sum_{t=0}^{\infty} \beta_{p}^{t}\left[\varepsilon_{t}^{c} \log \left(c_{p, t}-b c_{p, t-1}\right)+\varepsilon_{t}^{h} \varkappa \log h_{p, t}-\psi \frac{l_{p, t}^{1+\eta}}{1+\eta}\right],
$$

where $c_{p, t}$ denotes consumption of non-durable goods for the patient households, $h_{p, t}$ the stock of houses at the end of period $t$, and $l_{p, t}$ the hours worked. $\varepsilon_{t}^{c}$ is a consumption demand shock that obeys

$$
\log \varepsilon_{t}^{c}=\rho^{c} \log \varepsilon_{t-1}^{c}+\zeta_{t}^{c},
$$

and $\varepsilon_{t}^{h}$ is a housing demand shock that follows

$$
\log \varepsilon_{t}^{h}=\rho^{h} \log \varepsilon_{t-1}^{h}+\zeta_{t}^{h},
$$


with both $\zeta_{t}^{c}$ and $\zeta_{t}^{h}$ being zero-mean i.i.d. random variables. All variables are in per-capita real terms. The stock of houses evolves according to

$$
h_{p, t}=\left(1-\delta^{h}\right) h_{p, t-1}+i_{p, t}^{h},
$$

where $i_{p, t}^{h}$ is residential investment (i.e., new houses) and $\delta^{h}$ is the rate of depreciation of the housing stock. The household faces the following budget constraint:

$$
P_{t} c_{p, t}+P_{t}^{h} i_{p, t}^{h}+D_{t}+D_{t}^{*} e_{t} \leq W_{p, t} l_{p, t}+R_{t-1} D_{t-1}+D_{t-1}^{*} R_{t-1}^{*} \iota_{t-1} e_{t}-T_{t}+P_{t} \Pi_{t}
$$

where $P_{t}$ and $P_{t}^{h}$ are the prices of the consumption good and of houses, while $R_{t}$ and $W_{p, t}$ are the nominal interest rate and wage rate. $D_{t}$ is the amount of deposits by the end of period $t$, and it is carried into period $t+1$. Following Iacoviello (2005), it is assumed that it is the patient households (not the impatient ones) who pay tax $T_{t}$, and receive $\Pi_{t}$, which includes the profits from the retailers, plus the value of the assets received from the exiting bankers, minus the transfer to the newly entered bankers. ${ }^{2}$ We assume that the patient households also have the opportunity to buy foreign bonds $D_{t}^{*}$, and the nominal exchange rate at time $t$ is $e_{t}$. The foreign nominal interest rate is denoted by $R_{t-1}^{*}$. Following Schmitt-Grohé and Uribe (2003) we assume that $\iota_{t-1}$, the country-specific risk premium, is an increasing function of the net foreign-debt-to-GDP ratio:

$$
\iota_{t}=\exp \left(-v \frac{e_{t} D_{t}^{*}}{P_{t} y_{t}}\right)
$$

where $v>0, y_{t}$ is real GDP and $D_{t}^{*}$ the total level of indebtedness of the economy.

Define $q_{t}=\frac{P_{t}^{h}}{P_{t}}, f_{t}=\frac{e_{t} P_{t}^{*}}{P_{t}}$ (the real exchange rate), $w_{p, t}=\frac{W_{p, t}}{P_{t}}, t_{t}=\frac{T_{t}}{P_{t}}, d_{t}=\frac{D_{t}}{P_{t}}$, and $d_{t}^{*}=\frac{D_{t}^{*}}{P_{t}^{*}}$. Then we obtain the budget constraint in real terms:

$$
c_{p, t}+q_{t} i_{p, t}^{h}+d_{t}+d_{t}^{*} f_{t} \leq w_{p, t} l_{p, t}+R_{t-1} \frac{d_{t-1}}{\pi_{t}}+R_{t-1}^{*} \frac{d_{t-1}^{*} \iota_{t-1}}{\pi_{t}^{*}} f_{t}-t_{t}+\Pi_{t} .
$$

And equation (4) in real term becomes

$$
\iota_{t}=\exp \left(-v \frac{f_{t} d_{t}^{*}}{y_{t}}\right) .
$$

Households maximize their life-time utility (1) subject to constraints (2) and (5) by choosing $c_{p, t}, d_{t}, d_{t}^{*}, l_{p, t}, i_{p, t}^{h}$ and $h_{p, t}$. Let $\beta_{p}^{t} \lambda_{1, t}^{p}$ and $\beta_{p}^{t} \lambda_{2, t}^{p}$ be the Lagrangian multipliers associated with constraints (5) and (2). Then the first-order conditions are:

$c_{p, t}$ :

$$
\varepsilon_{t}^{c} \frac{1}{c_{p, t}-b c_{p, t-1}}-\beta_{p} b E_{t} \varepsilon_{t+1}^{c} \frac{1}{c_{p, t+1}-b c_{p, t}}-\lambda_{1, t}^{p}=0
$$

$d_{t}:$

$$
\lambda_{1, t}^{p}=E_{t} \beta_{p} R_{t} \frac{\lambda_{1, t+1}^{p}}{\pi_{t+1}}
$$

\footnotetext{
${ }^{2}$ Given the lump-sum nature, the optimal allocations are not affected by this assumption.
} 
$d_{t}^{*}:$

$$
\lambda_{1, t}^{p} f_{t}=E_{t} \beta_{p} R_{t}^{*} \iota_{t} f_{t+1} \frac{\lambda_{1, t+1}^{p}}{\pi_{t+1}^{*}}
$$

$l_{p, t}:$

$$
\psi l_{p, t}^{\eta}=\lambda_{1, t}^{p} w_{p, t}
$$

$i_{p, t}^{h}$ :

$$
\lambda_{1, t}^{p} q_{t}=\lambda_{2, t}^{p},
$$

$h_{p, t}:$

$$
\frac{\varepsilon_{t}^{h} \varkappa}{h_{p, t}}-\lambda_{2, t}^{p}+E_{t} \beta_{p} \lambda_{2, t+1}^{p}\left(1-\delta^{h}\right)=0 .
$$

Combining (7) and (8) yields the Euler equation for consumption. Equations (11) and (12) give us the Euler equation for housing:

$$
\frac{\varepsilon_{t}^{h} \varkappa}{h_{p, t}}+\beta_{p} E_{t} \lambda_{1, t+1}^{p} q_{t+1}\left(1-\delta^{h}\right)=q_{t} \lambda_{1, t}^{p}
$$

And (7) together with (10) show the consumption-leisure trade-off.

\subsubsection{Impatient households' problem}

An impatient household faces a problem similar to that faced by a patient household except that they are subject to an additional borrowing constraint. The impatient households maximize their lifetime utility

$$
E_{0} \sum_{t=0}^{\infty} \beta_{i p}^{t}\left[\varepsilon_{t}^{c} \log \left(c_{i p, t}-b c_{i p, t-1}\right)+\varepsilon_{t}^{h} \varkappa \log h_{i p, t}-\psi \frac{l_{i p, t}^{1+\eta}}{1+\eta}\right],
$$

subject to the housing accumulation equation

$$
h_{i p, t}=\left(1-\delta^{h}\right) h_{i p, t-1}+i_{i p, t}^{h}
$$

and the budget constraint

$$
P_{t} c_{i p, t}+P_{t}^{h} i_{i p, t}^{h}+R_{t-1}^{\ell} \mathcal{L}_{t-1} \leq W_{i p, t} l_{i p, t}+\mathcal{L}_{t}
$$

where $\mathcal{L}_{t}$ denotes the amount of loan that the impatient households take from the financial intermediaries. Note that the borrowing rate $R_{t-1}^{\ell}$ is different from the deposit rate $R_{t-1}$. The section on financial intermediaries below will provide detailed comments on why these two rates differ. Equation (15) can be expressed in real terms as follows:

$$
c_{i p, t}+q_{t} i_{i p, t}^{h}+R_{t-1}^{\ell} \frac{\ell_{t-1}}{\pi_{t}} \leq w_{i p, t} l_{i p, t}+\ell_{t}
$$


where $\ell_{t}=\mathcal{L}_{t} / P_{t}$. Following Iacoviello (2013), we assume that the impatient households are subject to the following borrowing constraint:

$$
\mathcal{L}_{t} \leq \rho^{\ell} \mathcal{L}_{t-1}+\left(1-\rho^{\ell}\right) E_{t}\left(\frac{\varepsilon_{t}^{\theta} \theta P_{t+1}^{h} h_{i p, t}\left(1-\delta^{h}\right)}{R_{t}^{\ell}}\right) .
$$

When $\rho^{\ell}=0$, equation (17) is reduced to the standard collateral constraint

$$
\mathcal{L}_{t} \leq E_{t}\left(\frac{\varepsilon_{t}^{\theta} \theta P_{t+1}^{h} h_{i p, t}\left(1-\delta^{h}\right)}{R_{t}^{\ell}}\right),
$$

that is, the maximum amount that an impatient household can borrow is a fraction $\theta$ of their housing wealth $P_{t+1}^{h} h_{i p, t}\left(1-\delta^{h}\right)$. The borrowing constraint in real terms is

$$
\ell_{t} \leq \rho^{\ell} \frac{\ell_{t-1}}{\pi_{t}}+\left(1-\rho^{\ell}\right) E_{t}\left(\frac{\varepsilon_{t}^{\theta} \theta q_{t+1} \pi_{t+1} h_{i p, t}\left(1-\delta^{h}\right)}{R_{t}^{\ell}}\right)
$$

The Lagrangian associated with the problem of an impatient household is:

$$
\begin{aligned}
\mathfrak{L}=\mathbf{E}_{0} \sum_{t=0}^{\infty} \beta_{i p}^{t}\left\{\varepsilon_{t}^{c} \log \left(c_{i p, t}-b c_{i p, t-1}\right)+\varepsilon_{t}^{h} \varkappa \log h_{i p, t}-\psi \frac{l_{i p, t}^{1+\eta}}{1+\eta}\right. & \\
-\lambda_{1, t}^{i p} & \left(c_{i p, t}+q_{t} i_{i p, t}^{h}+R_{t-1}^{\ell} \frac{\ell_{t-1}}{\pi_{t}}-w_{i p, t} l_{i p, t}-\ell_{t}\right) \\
& -\lambda_{2, t}^{i p}\left(h_{i p, t}-\left(1-\delta^{h}\right) h_{i p, t-1}-i_{i p, t}^{h}\right) \\
& \left.-\lambda_{3, t}^{i p}\left(\ell_{t}-\rho^{\ell} \frac{\ell_{t-1}}{\pi_{t}}-\left(1-\rho^{\ell}\right) \frac{\varepsilon_{t}^{\theta} \theta q_{t+1} \pi_{t+1} h_{i p, t}\left(1-\delta^{h}\right)}{R_{t}^{\ell}}\right)\right\} .
\end{aligned}
$$

And the first-order conditions are:

$c_{i p, t}$ :

$$
\varepsilon_{t}^{c} \frac{1}{c_{i p, t}-b c_{i p, t-1}}-\beta_{i p} E_{t} b \varepsilon_{t+1}^{c} \frac{1}{c_{i p, t+1}-b c_{i p, t}}-\lambda_{1, t}^{i p}=0,
$$

$\ell_{t}:$

$$
\lambda_{1, t}^{i p}=E_{t} \beta_{i p} R_{t}^{\ell} \frac{\lambda_{1, t+1}^{i p}}{\pi_{t+1}}+\lambda_{3, t}^{i p}-E_{t} \beta_{i p} \lambda_{3, t+1}^{i p} \frac{\rho^{\ell}}{\pi_{t+1}},
$$

$l_{i p, t}:$

$$
\psi l_{i p, t}^{\eta}=\lambda_{1, t}^{i p} w_{i p, t}
$$

$i_{i p, t}^{h}:$

$$
\lambda_{1, t}^{i p} q_{t}=\lambda_{2, t}^{i p},
$$

$h_{i p, t}:$

$$
\varepsilon_{t}^{h} \frac{\varkappa}{h_{i p, t}}-\lambda_{2, t}^{i p}+E_{t} \lambda_{2, t+1}^{i p} \beta_{i p}\left(1-\delta^{h}\right)+\left(1-\rho^{l}\right) \lambda_{3, t}^{i p} E_{t} \frac{\theta \varepsilon_{t}^{\theta} q_{t+1} \pi_{t+1}\left(1-\delta^{h}\right)}{R_{t}^{\ell}}=0 .
$$

Equations (21) and (22) give us the consumption Euler equation for the impatient households whereas (21) and (23) show the consumption-leisure trade-off. Combining equations (24) and (25) yields the Euler equation for housing. 


\subsection{Financial intermediaries}

At the beginning of period $t$, the net worth of each financial intermediary (bank) is $n_{t}$. The bank will fund intermediate goods producers' capital acquisition $k_{t}$ and lend mortgage loans $\ell_{t}^{b}=(1-a) \ell_{t}$ to the impatient households by issuing deposits $d_{t}^{b}=a d_{t}$ to the patient households and using their own equity or net worth $n_{t}$. We can think of the total assets $A_{t}$ as the total financial claims $S_{t}$ the bank buys. Thus, at the beginning of the period $t$, the total assets that the bank has is

$$
A_{t}=Q_{t} S_{t}=Q_{t}\left(q_{t}^{k} k_{t}+\ell_{t}^{b}\right)
$$

where $Q_{t}$ is the price of the claims and $q_{t}^{k}=P_{t}^{k} / P_{t}$ (see the subsection on capital producers below). The flow-of-funds equation is

$$
A_{t}=Q_{t}\left(q_{t}^{k} k_{t}+\ell_{t}^{b}\right)=d_{t}^{b}+n_{t}
$$

Let $R_{t}^{\ell}$ be the realized nominal return on the financial claims at the end of period $t$ (or at the beginning of period $t+1$ ), and $R_{t}$ the nominal return on the deposits at the end of period $t$. At the end of period $t$ (or at the beginning of period $t+1$ ), the banker's net worth $n_{t+1}$ is the gross payoff from assets that the banker funded at the beginning of the period, minus the borrowing costs:

$$
n_{t+1}=\frac{R_{t}^{\ell}}{\pi_{t+1}} Q_{t} S_{t}-\frac{R_{t}}{\pi_{t+1}} d_{t}^{b}=\frac{R_{t}^{\ell}}{\pi_{t+1}} Q_{t}\left(q_{t}^{k} k_{t}+\ell_{t}^{b}\right)-\frac{R_{t}}{\pi_{t+1}} d_{t}^{b}
$$

which can be further expressed as

$$
n_{t+1}=\left(\frac{R_{t}^{\ell}}{\pi_{t+1}}-\frac{R_{t}}{\pi_{t+1}}\right) Q_{t}\left(q_{t}^{k} k_{t}+\ell_{t}^{b}\right)+\frac{R_{t}}{\pi_{t+1}} n_{t}
$$

Let $s_{t}$ denote the difference between the lending rate $R_{t}^{\ell}$ and borrowing rate $R_{t}$ - the nominal risk premium. The existence of the risk premium is due to the fact that the banker faces a limitation on the deposits raised from the patient households. If there is no limitation on raising these deposits, the interest rate spread will disappear eventually. The increase in deposits will require a rise in the deposit rate, and the rise in bank's assets will generally lead to a decline in the rate of return on these assets.

In order to motivate the limitation on raising deposits, we follow Gertler and Kiyotaki (2015) and Gertler and Karadi (2011) to introduce the following moral hazard problem to the banking sector: at the end of each period $t$, the banker can choose to divert the fraction $\kappa$ of assets for personal use. The cost of this action is that the bank can be forced into bankruptcy at the beginning of the next period. In this environment, for the patient households to be willing to lend to the bank, the following incentive constraint must be satisfied:

$$
V_{t} \geq \kappa Q_{t} S_{t}
$$

that is, the present value of payout from operating the bank, $V_{t}$, must exceed the gain of diverting assets. There is a threshold level of deposits beyond which the bank would have the incentive to 
divert assets and default. In equilibrium, the patient households will choose not to expand their deposits beyond this threshold, and this results in emergence of an interest rate spread between the lending and borrowing rates in the model.

Given the financial frictions, the bank has the incentive to accumulate retained earnings in order to eventually use only his internal funds. To limit this possibility, we assume that bankers have a finite expected lifetime. In each period, bankers are subject to an i.i.d probability $\sigma$ of surviving and a probability of $1-\sigma$ of exiting. It is assumed that the bank pays dividends only when it exits. Thus, the objective of the bank is to maximize the expected present value of future dividends

$$
V_{t}=E_{t} \sum_{i=1}^{\infty}\left[\beta_{p}^{i} \Lambda_{t, t+i}(1-\sigma) \sigma^{i-1} n_{t+i}\right],
$$

which can be expressed recursively as

$$
V_{t}=E_{t}\left[\beta_{p} \Lambda_{t, t+1}(1-\sigma) n_{t+1}+\beta_{p} \Lambda_{t, t+1} \sigma V_{t+1}\right] .
$$

The bank's problem thus is as follows: given $Q_{t}$, the bank maximizes $V_{t}$ in equation (29) by choosing $d_{t}$ and $S_{t}$, subject to the incentive constraint (28) and the flow of funds constraints (26) and (27). Gertler and Kiyotaki (2015) show that $V_{t}$ can be expressed as a linear function of $S_{t}$ and $d_{t}$ as follows:

$$
V_{t}=v_{s t} S_{t}-v_{d t} d_{t}^{b}
$$

where $v_{s t}$ is the marginal value of assets at the end of period $t$, and $v_{d t}$ is the marginal cost of deposits. $V_{t}$ can also be expressed as

$$
V_{t}=\mu_{t} Q_{t} S_{t}+v_{d t} n_{t}
$$

where

$$
\mu_{t}=\frac{v_{s t}}{Q_{t}}-v_{d t}
$$

We can rewrite the incentive constraint (28) as

$$
\kappa Q_{t} S_{t} \leq \mu_{t} Q_{t} S_{t}+v_{d t} n_{t}
$$

When

$$
0<\mu_{t}<\kappa
$$

i.e., the excess marginal value from continuing to manage assets is positive but less than the marginal benefit from diverting funds, the incentive constraint is binding:

$$
\kappa Q_{t} S_{t}=\mu_{t} Q_{t} S_{t}+v_{d t} n_{t}
$$

Let $\phi_{t}$ denote the maximum asset-to-net worth ratio (leverage); then we have

$$
\phi_{t}=\frac{Q_{t} S_{t}}{n_{t}}=\frac{v_{d t}}{\kappa-\mu_{t}} .
$$


Using equations (26) and (27), the value function (29) can be further expressed as

$$
\begin{aligned}
V_{t}= & \mu_{t} Q_{t} S_{t}+v_{d t} n_{t}= \\
& E_{t}\left[(1-\sigma)+\sigma\left(v_{d t+1}+\phi_{t+1} \mu_{t+1}\right)\right]\left[\left(\frac{R_{t}^{\ell}}{\pi_{t+1}}-\frac{R_{t}}{\pi_{t+1}}\right) Q_{t} S_{t}+R_{t+1} n_{t}\right] .
\end{aligned}
$$

Then it is easy to verify that

$$
\begin{gathered}
\mu_{t}=\beta_{p} \Lambda_{t, t+1} E_{t}\left[\left(\frac{R_{t}^{\ell}}{\pi_{t+1}}-\frac{R_{t}}{\pi_{t+1}}\right) \Omega_{t+1}\right] \\
v_{d t}=\beta_{p} \Lambda_{t, t+1} E_{t}\left[R_{t+1} \Omega_{t+1}\right]
\end{gathered}
$$

and

$$
\Omega_{t+1}=1-\sigma+\sigma\left(v_{d t+1}+\phi_{t+1} \mu_{t+1}\right)
$$

where $\Omega_{t+1}$ can be thought of as a weighted average of the marginal values of net worth of the exiting bankers (their fraction is $1-\sigma$ ) and surviving bankers (their fraction is $\sigma$ ). Equation (39) shows that $\mu_{t}$ depends on $\left(R_{t}^{\ell} / \pi_{t+1}-R_{t} / \pi_{t+1}\right)$, the excess return per unit of bank assets. Note that $v_{d t}$ depends on $R_{t+1}$, the marginal cost of deposits. Let $\lambda_{t}^{b}$ be the Lagrangian multiplier for the incentive constraint. Then we have

$$
\lambda_{t}^{b}=\frac{\mu_{t}}{\kappa \varepsilon_{t}^{\kappa}-\mu_{t}},
$$

where $\varepsilon_{t}^{\kappa}$ is a shock to the fraction of assets that can be diverted, which can be thought of as a disturbance that affects the perceived riskiness of the banking sector. This shock follows

$$
\log \varepsilon_{t}^{\kappa}=\rho^{\kappa} \log \varepsilon_{t-1}^{\kappa}+\zeta_{t}^{\kappa}
$$

When the incentive constraint is not binding, $\lambda_{t}^{b}=0$. In this case, $\mu_{t}=0$. The unlimited arbitrage by bankers would drive the excess return $\left(R_{t+1}^{\ell}-R_{t+1}\right)$ to zero. However, as long as the constraint is binding, limits to arbitrage will lead to a positive expected excess return: $R_{t+1}^{\ell}>R_{t+1}$. The tighter the constraint is, the larger $\lambda_{t}^{b}$ is, and the larger the excess return is. In the model, a decline in asset values caused by a fall in house prices will tighten the incentive constraint, and thus the excess return is much higher in the crisis period.

Recall that in each period, bankers are subject to an i.i.d probability of surviving $\sigma$. We denote the net worth of the existing bankers as $n_{t}^{e}$, and that of the newly entered bankers as $n_{t}^{n}$. Following Gertler and Karadi (2011), we assume that the patient households receive $(1-\sigma) Q_{t-1} S_{t-1}$ amount of assets of the exiting bankers at the end of period $t$, and they transfer a fraction $\omega /(1-\sigma)$ of the received transfer to the newly entered bankers at the beginning of the next period. Thus, the total net worth at the beginning of the period $t$ is

$$
n_{t}=n_{t}^{n}+n_{t}^{e}
$$


with

$$
n_{t}^{e}=\sigma\left[\left(\frac{R_{t-1}^{\ell}}{\pi_{t}}-\frac{R_{t-1}}{\pi_{t}}\right) \phi_{t-1}+\frac{R_{t-1}}{\pi_{t}}\right] n_{t-1}
$$

and

$$
n_{t}^{n}=\frac{\omega}{1-\sigma}(1-\sigma) Q_{t-1} S_{t-1}=\omega Q_{t-1} S_{t-1}
$$

\subsection{Goods and House Producers}

\subsubsection{Capital Producers}

Capital producers operate in a competitive market. Capital production is assumed to be subject to an investment-specific shock, $\tau_{t}^{k}$. Capital producers purchase the final goods from retailers, $i_{t}^{k}$, and produce efficient investment goods, $\tau_{t}^{k} i_{t}^{k}$. Following Christiano et al. (2005), we assume that capital producers face investment adjustment costs $S\left(i_{t}^{k} / i_{t-1}^{k}\right)$, such that in steady state $S=S^{\prime}=0$ and $S^{\prime \prime}=\chi^{k}$, where $\chi^{k}>0$ is an investment adjustment cost parameter. The production function of capital goods is

$$
f\left(i_{t}^{k}\right)=i_{t}^{k} \tau_{t}^{k}-S\left(i_{t}^{k} / i_{t-1}^{k}\right) i_{t}^{k}
$$

At the end of period $t$, the capital producer solves for $i_{t}^{k}$ to maximize

$$
E_{t} \sum_{s=0} \beta_{p}^{s} \Lambda_{t+s, t+s+1}\left[P_{t+s}^{k}\left[\tau_{t+s}^{k}-S\left(i_{t+s}^{k} / i_{t+s-1}^{k}\right)\right] i_{t+s}^{k}-P_{t+s} i_{t+s}^{k}\right],
$$

where $\Lambda_{t+s, t+s+1}=\lambda_{1, t+s+1}^{p} / \lambda_{1, t+s}^{p}$. Let the functional form for $S\left(i_{t}^{k} / i_{t-1}^{k}\right)$ be

$$
S\left(i_{t}^{k} / i_{t-1}^{k}\right)=0.5 \chi^{k}\left(i_{t}^{k} / i_{t-1}^{k}-1\right)^{2}
$$

and

$$
q_{t}^{k}=\frac{P_{t}^{k}}{P_{t}}
$$

Then the first-order condition for $i_{t}^{k}$ is

$$
\begin{aligned}
\tau_{t}^{k} q_{t}^{k}=1+0.5 q_{t}^{k} \chi^{k}\left(i_{t}^{k} / i_{t-1}^{k}-1\right)^{2}+ & q_{t}^{k} \chi^{k}\left(i_{t}^{k} / i_{t-1}^{k}-1\right)\left(i_{t}^{k} / i_{t-1}^{k}\right) \\
& -E_{t}\left[\beta_{p} \Lambda_{t+1, t+2} q_{t+1}^{k} \chi^{k}\left(i_{t}^{k} / i_{t-1}^{k}-1\right)\left(i_{t}^{k} / i_{t-1}^{k}-1\right)^{2}\right] .
\end{aligned}
$$

We assume that $\tau_{t}^{k}$, an investment technology shock, follows the first-order autoregressive process

$$
\log \tau_{t}^{k}=\rho_{k} \log \tau_{t-1}^{k}+\varepsilon_{t}^{\tau^{k}}, \quad \varepsilon_{t}^{\tau^{k}} \sim \text { i.i.d.N }\left(0, \sigma_{\varepsilon^{\tau k}}^{2}\right) .
$$

The aggregate stock of capital evolves as follows:

$$
k_{t}=\left(1-\delta^{k}\right) k_{t-1}+\tau_{t}^{k} i_{t}^{k}
$$

It is also assumed that households own capital producers and are the recipients of their profits. 


\subsubsection{House Producers}

Similarly, new houses are produced by perfectly competitive firms, which use the final goods as an input of production. The production is subject to housing investment adjustment costs $S_{h}\left(i_{t}^{h} / i_{t-1}^{h}\right)$, such that in steady state $S_{h}=S_{h}^{\prime}=0$ and $S_{h}^{\prime \prime}=\chi^{h}$, where $\chi^{h}>0$ is an investment adjustment cost parameter. The house producer solves for $i_{t}^{h}$ to maximize

$$
E_{t} \sum_{s=0} \beta_{p}^{s} \Lambda_{t+s, t+s+1}\left[P_{t+s}^{h} h_{t+s}-P_{t+s} i_{t+s}^{h}\right] .
$$

The production of new house follows the following technology:

$$
h_{t}=\left[\tau_{t}^{h}-S_{h}\left(i_{t}^{h} / i_{t-1}^{h}\right)\right] i_{t}^{h},
$$

where $\tau_{t}^{h}$ is a shock to the house investment technology and follows the first-order autoregressive process

$$
\log \tau_{t}^{h}=\rho_{z} \log \tau_{t-1}^{h}+\varepsilon_{t}^{\tau^{h}}, \quad \varepsilon_{t}^{\tau^{h}} \sim \text { i.i.d.N }\left(0, \sigma_{\varepsilon^{\tau^{h}}}^{2}\right) .
$$

Again, we assume that the functional form of $S_{h}\left(i_{t}^{h} / i_{t-1}^{h}\right)$ is

$$
S_{h}\left(i_{t}^{h} / i_{t-1}^{h}\right)=0.5 \chi^{h}\left(i_{t}^{h} / i_{t-1}^{h}-1\right)^{2} .
$$

The first-order condition for $i_{t}^{h}$ is

$$
\begin{aligned}
\tau_{t}^{h} q_{t}=1+0.5 q_{t} \chi^{h}\left(i_{t}^{h} / i_{t-1}^{h}-1\right)^{2}+q_{t} \chi^{h} & \left(i_{t}^{h} / i_{t-1}^{h}-1\right)\left(i_{t}^{h} / i_{t-1}^{h}\right) \\
& -E_{t}\left[\beta_{p} \Lambda_{t+1, t+2} q_{t+1} \chi^{h}\left(i_{t}^{h} / i_{t-1}^{h}-1\right)\left(i_{t}^{h} / i_{t-1}^{h}\right)^{2}\right] .
\end{aligned}
$$

Total house stock evolves according to

$$
h_{t}=\left(1-\delta^{h}\right) h_{t-1}+\tau_{t}^{h} i_{t}^{h} .
$$

We also assume that households own the housing sector.

\subsubsection{Wholesale Goods Sector}

The domestic wholesale goods $y_{t}^{d}$ are produced by using the following constant-return-to-scale technology

$$
y_{t}^{d}=z_{t} k_{t-1}^{\gamma}\left[\left(a l_{p, t}\right)^{\alpha}\left((1-a) l_{i p, t}\right)^{1-\alpha}\right]^{1-\gamma},
$$

where $z_{t}$ is a shock to technology that follows

$$
\log z_{t}=\rho^{z} \log z_{t-1}+\varsigma_{t}^{z}
$$

It is assumed that the wholesale goods producers acquire capital from capital producers at the end of period $(t-1)$ for use in production in period $t$. After production, they sell the depreciated capital in the open market. 
Each period, the firms borrow from the financial intermediaries to finance their capital acquisition. The firms issue claim $S_{t}^{f}$ at the price $Q_{t}$ so that

$$
S_{t}^{f} Q_{t}=Q_{t} k_{t}
$$

where $k_{t}$ is the capital acquired at the end of period $t$. Let $P_{t}^{w}$ be the wholesale goods price and define $p_{t}^{w}=\frac{P_{t}^{w}}{P_{t}}$ and $q_{t}^{k}=\frac{Q_{t}}{P_{t}}$. The firms borrow at the rate $R_{t}^{\ell}$. The firms are competitive and earn zero profits, and we assume that at the end of each period they pay out the realized return to capital to the intermediaries. In each period, the labour demand decisions for the firms are static:

$$
\begin{gathered}
p_{t}^{w} \alpha(1-\gamma) \frac{y_{t}^{d}}{a l_{p, t}}=w_{p, t}, \\
p_{t}^{w}(1-\alpha)(1-\gamma) \frac{y_{t}^{d}}{(1-a) l_{i p, t}}=w_{i p, t}
\end{gathered}
$$

In each period, the firms also need to choose $k_{t}$, and the first-order condition for $k_{t}$ is derived by maximizing

$$
E_{t}\left[p_{t+1}^{w} y_{t+1}^{d}+(1-\delta) q_{t+1}^{k} k_{t}-w_{p, t+1} l_{p, t+1}-w_{i p, t+1} l_{i p, t+1}-\frac{R_{t}^{\ell}}{\pi_{t+1}} q_{t}^{k} k_{t}\right] .
$$

The first-order condition is

$$
E_{t} \frac{R_{t}^{\ell}}{\pi_{t+1}}=\frac{E_{t}\left[r_{t+1}^{k}+q_{t+1}^{k}(1-\delta)\right]}{q_{t}^{k}}
$$

where $r_{t+1}^{k}=p_{t+1}^{w} \gamma \frac{y_{t+1}^{d}}{k_{t}}$.

\subsubsection{Retailers for Domestic Goods}

There is a continuum of retailers of mass 1 indexed by $j$. They buy intermediate goods from wholesale goods producers at $P_{t}^{w}$ in a competitive market and differentiate the goods at no costs into domestic final goods $y_{d, t}(j)$, and sell them at the price $P_{d, t}(j)$.

The domestic final goods $y_{d, t}$ is the composite of individual variety: $y_{d, t}=\left[\int_{0}^{1} y_{d, t}(j)^{\frac{\varepsilon-1}{\varepsilon}} d j\right]^{\frac{\varepsilon}{\varepsilon-1}}$. The price index that minimizes the final producers' cost function is

$$
P_{d, t}=\left[\int_{0}^{1} P_{d, t}(j)^{1-\varepsilon} d j\right]^{\frac{1}{1-\varepsilon}}
$$

The demand function faced by each retailer is given by

$$
y_{d, t}(j)=\left(\frac{P_{d, t}(j)}{P_{d, t}}\right)^{-\varepsilon} y_{d, t}
$$


Following Calvo (1983), we assume that in each period, only a fraction $1-\nu$ of retailers reset their prices, while the remaining retailers keep their prices unchanged. The retailer $j$ chooses $P_{i, t}(j)$ to maximize its expected total profits over the periods during which its prices remain fixed:

$$
E_{t} \Sigma_{i=0}^{\infty} \nu^{i} \Delta_{i, t+i}^{p}\left[P_{d, t}(j) y_{d, t+i}(j)-P_{t+i}^{w} y_{d, t+i}(j)\right],
$$

where $\Delta_{t, t+i}=\beta_{p} \frac{\lambda_{p, t+i}}{\lambda_{p, t}} \frac{P_{t}}{P_{t+i}}$ is the stochastic discount factor for nominal payoffs. ${ }^{3}$ Define $\tilde{\Delta}_{t, t+i}=$ $\beta_{p} \frac{\lambda_{p, t+i}}{\lambda_{p, t}}$. Then the stochastic discount factor can be expressed as $\Delta_{t, t+i}=\tilde{\Delta}_{t, t+i} \frac{P_{t}}{P_{t+i}}$. Let $\tilde{P}_{d, t}$ be the optimal price chosen by all firms adjusting at time $t$.

The first-order condition for the optimal price is:

$$
\tilde{P}_{d, t}=\left(\frac{\varepsilon}{\varepsilon-1}\right) \frac{E_{t} \sum_{i=0}^{\infty} \nu^{i} \tilde{\Delta}_{t, t+i} \frac{P_{t}}{P_{t+i}} P_{t+i}^{w} y_{d, t+i}\left(\frac{1}{P_{d, t+i}}\right)^{-\varepsilon}}{E_{t} \sum_{i=0}^{\infty} \nu^{i} \tilde{\Delta}_{t, t+i} \frac{P_{t}}{P_{t+i}} y_{d, t+i}\left(\frac{1}{P_{d, t+i}}\right)^{-\varepsilon}} .
$$

Define $p_{t+i}^{w}=\frac{P_{t+i}^{w}}{P_{t+i}}$. Then we have

$$
\tilde{P}_{d, t}=\left(\frac{\varepsilon}{\varepsilon-1}\right) \frac{E_{t} \sum_{i=0}^{\infty} \nu^{i} \tilde{\Delta}_{t, t+i} p_{t+i}^{w} y_{d, t+i}\left(\frac{1}{P_{d, t+i}}\right)^{-\varepsilon}}{E_{t} \sum_{i=0}^{\infty} \nu^{i} \tilde{\Delta}_{t, t+i} \frac{P_{d, t+i}}{P_{t+i}} y_{d, t+i}\left(\frac{1}{P_{d, t+i}}\right)^{1-\varepsilon}} .
$$

The aggregate price for domestic final goods evolves according to:

$$
P_{d, t}=\left[\nu P_{d, t-1}^{1-\varepsilon}+(1-\nu)\left(\tilde{P}_{d, t}\right)^{1-\varepsilon}\right]^{\frac{1}{1-\varepsilon}} .
$$

Since retailers face monopolistic competition, the profits are positive.

\subsubsection{Import and Export}

Import There is a continuum of retailers of mass 1 indexed by $j$. They buy imported intermediate goods at $e_{t} P_{t}^{*}$ in a competitive market and differentiate the goods at no costs into $y_{f, t}(j)$ and sell them at the price $P_{f, t}(j)$.

The final goods $y_{f, t}$ is the composite of individual variety:

$$
y_{f, t}=\left[\int_{0}^{1} y_{f, t}(j)^{\frac{\varepsilon-1}{\varepsilon}} d j\right]^{\frac{\varepsilon}{\varepsilon-1}} .
$$

The price index that minimizes the final producers' cost function is

$$
P_{f, t}=\left[\int_{0}^{1} P_{f, t}(j)^{1-\varepsilon} d j\right]^{\frac{1}{1-\varepsilon}} .
$$

\footnotetext{
${ }^{3}$ Since the patient households own the firms, we assume that the firms discount the future as the same rate as the patient households, and use the patient households' marginal utility to compute $\Delta_{t, i}$.
} 
The demand function faced by each retailer is given by

$$
y_{f, t}(j)=\left(\frac{P_{f, t}(j)}{P_{f, t}}\right)^{-\varepsilon} y_{f, t} .
$$

Similar to the previous section, we assume that in each period, only a fraction $1-\nu$ of retailers reset their prices, while the remaining retailers keep their prices unchanged. The retailer $j$ chooses $P_{f, t}(j)$ to maximize its expected real total profit over the periods during which its price remains fixed:

$$
E_{t} \Sigma_{i=0}^{\infty} \nu^{i} \Delta_{i, t+i}\left[P_{t}^{f}(j) y_{t+i}^{f}-e_{t} P_{t}^{*} y_{t+i}^{f}(j)\right] .
$$

Let $\tilde{P}_{f, t}$ be the optimal price chosen by all firms adjusting at time $t$ in the imported goods sector.

Given that $f_{t}=\frac{e_{t} P_{t}^{*}}{P_{t}}$, the first-order condition for the optimal price is:

$$
\tilde{P}_{f, t}=\left(\frac{\varepsilon}{\varepsilon-1}\right) \frac{E_{t} \sum_{i=0}^{\infty} \nu^{i} \tilde{\Delta}_{i, t+i} f_{t+i} y_{t+i}\left(\frac{1}{P_{f, t+i}}\right)^{-\varepsilon}}{E_{t} \sum_{i=0}^{\infty} \nu^{i} \tilde{\Delta}_{i, t+i} y_{t+i} \frac{P_{f, t+i}}{P_{t+i}}\left(\frac{1}{P_{f, t+i}}\right)^{1-\varepsilon}} .
$$

The aggregate price evolves according to

$$
P_{f, t}=\left[\nu P_{f, t-1}^{1-\varepsilon}+(1-\nu) \tilde{P}_{f, t}^{1-\varepsilon}\right]^{\frac{1}{1-\varepsilon}} .
$$

Export The aggregate foreign demand function for exports is

$$
y_{t}^{e}=\varpi\left(\frac{P_{t}}{e_{t} P_{t}^{*}}\right)^{-\varsigma} y_{t}^{*}
$$

In real terms, it is

$$
y_{t}^{e}=\varpi\left(\frac{1}{f_{t}}\right)^{-\varsigma} y_{t}^{*}
$$

where $y_{t}^{*}$ is foreign output. The elasticity of demand for domestically manufactured goods among foreigners is $-\varsigma$, and $\varpi>0$ is a parameter determining the fraction of domestic exports in foreign spending.

\subsection{Aggregate final goods producers}

A representative firm acts in a perfectly competitive market and uses domestic goods and imported goods to produce the final consumption goods, $y_{t}$, according to the following CES technology:

$$
y_{t}=\left[\left(\omega_{d}\right)^{\frac{1}{\nu}}\left(y_{d, t}\right)^{\frac{\nu-1}{\nu}}+\left(\omega_{f}\right)^{\frac{1}{\nu}}\left(y_{f, t}\right)^{\frac{\nu-1}{\nu}}\right]^{\frac{\nu}{\nu-1}},
$$

where $\omega_{d}$ and $\omega_{f}$ denote the shares of domestically produced and imported composite sectoral goods in the final goods respectively, with $\omega_{d}+\omega_{f}=1$, and $\nu>0$ is the elasticity of substitution between the sectoral goods. 
The demand for domestic and imported goods are

$$
y_{d, t}=\omega_{d} y_{t}\left(\frac{P_{d, t}}{P_{t}}\right)^{-\nu}
$$

and

$$
y_{f, t}=\omega_{f} y_{t}\left(\frac{P_{f, t}}{P_{t}}\right)^{-\nu} .
$$

The aggregate price index is

$$
P_{t}=\left[\omega_{d} P_{d, t}^{1-\nu}+\omega_{f} P_{f, t}^{1-\nu}\right]^{\frac{1}{1-\nu}}
$$

\subsection{Government}

Government expenditures are financed by a lump sum tax:

$$
G_{t}=a T_{t}
$$

which, in real terms, is

$$
g_{t}=a t_{t}
$$

where $g_{t}$ follows an AR(1) process:

$$
\log g_{t}=\left(1-\rho_{g}\right) \log g_{s s}+\rho_{g} \log g_{t-1}+\varepsilon_{t}^{g}, \quad \varepsilon_{t}^{g} \sim \text { i.i.d.N }\left(0, \sigma_{\varepsilon^{g}}^{2}\right) .
$$

\subsection{Monetary Policy}

The central bank is assumed to operate according to the standard Taylor Rule. It adjusts the nominal interest rate, $R_{t}$, in response to deviations of inflation, $\pi_{t}$, from its steady-state value, $\pi$, and output, $y_{t}$, from its steady-state level, $y$ :

$$
\frac{R_{t}}{R}=\left(\frac{R_{t-1}}{R}\right)^{\rho_{r}}\left(\left(\frac{\pi_{t}}{\pi}\right)^{\rho_{\pi}}\left(\frac{y_{t}}{y}\right)^{\rho_{y}}\right)^{1-\rho_{r}} e^{\varepsilon_{t}^{m}},
$$

where $R, \pi$ and $y_{t}$ are the steady-state values of $R_{t}, \pi_{t}$ and $y_{c, t}$, and $\varepsilon_{t}^{m}$ is a monetary policy shock which follows

$$
\varepsilon_{t}^{m} \sim \text { i.i.d. } N\left(0, \sigma_{\varepsilon^{m}}\right) .
$$

And $\rho_{\pi}, \rho_{y}$ and $\rho_{r}$ are policy coefficients chosen by the central bank. 


\subsection{Rest of the world}

Given that Canada is a small open economy, we assume that domestic developments do not affect the rest of the world. However, the foreign economy has an impact on the Canadian economy. We assume that the foreign output $y_{t}^{*}$, foreign interest rate $R_{t}^{*}$, and inflation $\pi_{t}^{*}$ follow the following processes:

$$
\log x_{t}=\left(1-\rho^{x}\right) \log x+\rho^{x} \log x_{t-1}+\varepsilon_{t}^{x}, \quad \varepsilon_{t}^{x} \text { iid } \backsim N\left(0, \sigma_{\varepsilon^{x}}\right), \quad 0<\rho^{x}<1,
$$

where $x_{t} \in\left\{R_{t}^{*}, y_{t}^{*}, \pi_{t}^{*}\right\}, x>0$ is a steady-state value of $x_{t}, \rho^{x}$ an autoregressive coefficient, and $\varepsilon_{t}^{x}$ is a vector of uncorrelated and normally distributed innovations with zero means and standard deviations $\sigma_{\varepsilon^{x}}$.

\subsection{Market Clearing}

In the goods market, the following market clearing condition holds:

$$
a c_{p, t}+(1-a) c_{i p, t}+g_{t}+a i_{p, t}^{h}+(1-a) i_{i p, t}^{h}+i_{t}^{k}+0.5 \chi^{k}\left(i_{t}^{k} / i_{t-1}^{k}-1\right)^{2}+0.5 \chi^{h}\left(i_{t}^{h} / i_{t-1}^{h}-1\right)^{2}=y_{t} .
$$

And in the housing market,

$$
(1-a) h_{i p, t}+a h_{p, t}=h_{t} .
$$

The current account equation is obtained by combining the household's budget constraint, government budget constraint, and single-period profit functions of tradable and non-tradable goods producing firms, and foreign goods importers. Under the producer currency pricing (PCP) assumption, the current account equation in real terms is given by

$$
d_{t}^{*} f_{t}=R_{t-1}^{*} \frac{d_{t-1}^{*} \iota_{t-1}}{\pi_{t}^{*}} f_{t}+y_{t}^{e}-f_{t} y_{f, t}
$$

\section{Data and Estimation}

We estimate the model using the Bayesian approach. In what follows, we present the data, the calibrated parameters, the priors and the estimation results.

\subsection{Data}

We estimate the model using Canadian quarterly data from 1991Q1 to 2015Q3. We use ten time series as observables given that the model allows for ten shocks. The time series are: output, business investment, consumption, government spending, nominal interest rate, inflation, housing prices, foreign output, foreign nominal interest rate and foreign inflation. Appendix 1 describes the data construction. For the real variables, we detrend the logarithm of each variable using a HP filter. The nominal variables are demeaned. The detrended and demeaned data are plotted in Figure 2. 
Table 1: Calibrated Parameters

\begin{tabular}{lll}
\hline \hline Household & & \\
\hline Discount rate for patient households & $\beta^{p}$ & 0.9925 \\
Discount rate for impatient households & $\beta^{i p}$ & 0.94 \\
Fraction of patient households & $a$ & 0.40 \\
Relative utility weight of labour & $\psi$ & 1 \\
Relative utility weight of housing & $\varkappa$ & 0.37 \\
Inverse Frisch elasticity of labour supply & $\eta$ & 1.01 \\
House depreciation rate & $\delta^{h}$ & 0.008 \\
Collateral constraint parameter & $\theta$ & 0.5 \\
Persistence of household debt & $\rho^{l}$ & 0.95 \\
\hline Financial intermediaries & & \\
\hline Fraction of assets that can be diverted & $\lambda$ & 0.382 \\
Survival rate of the bankers & $\sigma$ & 0.97 \\
\hline Intermediate good producers & & \\
\hline Capital share & $\gamma$ & 0.33 \\
Share of patient households labour income & $\alpha$ & 0.5 \\
Capital depreciation rate & $\delta$ & 0.025 \\
Calvo pricing parameter & $\varepsilon$ & 11 \\
\hline
\end{tabular}

\subsection{Calibrated Parameters}

Table 1 summarize the calibrated parameters. We set the discount rate for the patient households to 0.9925 , which implies an annualized steady-state deposit rate $R_{t}$ of 4 percent. For the impatient households, we follow Iacoviello (2015) and set the discount rate at 0.94 . The fraction of impatient households is 60 per cent as suggested by Hall (2011) and Justiniano et al. (2013). We set the weight $\psi$ on leisure in the household utility function at 1 since it only affects the scale of the economy. We also set $\eta$ to 1.01 so that the Frisch elasticity of labor supply is about $1 .{ }^{4}$

The depreciation rate for houses $\delta^{h}$ is set to 0.008 , matching the target of the ratio of residential investment to GDP of 6.75 percent. In the literature, the loan-to-value ratio $\theta$ is usually set to a value between 0.8 and 0.9 , which is close to the value set by the LTV regulation. For example, currently in Canada, the LTV limit for new mortgages is set to 0.95 , and the LTV limit for mortgage refinancing is set to 0.8 . In our calibration, we set the loan-to-value ratio $\theta$ to 0.5 so that the steady-state debtto-GDP ratio is equal to the sample average of 0.71 . Although the value $\theta=0.5$ is lower than the standard value used in the literature, we think that it is reasonable given that not all households borrow up to the regulatory LTV limit. We set the persistence parameter for mortgage loans $\rho^{l}$ to 0.95 , capturing the fact that most mortgage loans are renegotiated every five years in Canada. We set the housing preference parameter $\varkappa$ to 0.37 ; this together with $\delta^{h}$ and $\theta$ implies that the average

\footnotetext{
${ }^{4}$ This value is a compromise between microeconometric estimates of the Frisch labor supply elasticity $(0$ to 0.5$)$ and the values used by macroeconomists to calibrate general equilibrium models ( 2 to 4 ).
} 
ratio of the market value of housing stock to quarterly GDP is 7.56.

For the production function, we set the capital share $\alpha$ to 0.33 , and wage share of the impatient households $(1-\gamma)$ to 50 percent, which is the estimate in Iacoviello (2005). The depreciation rate for capital is set to 0.025 . We follow Gertler and Karadi (2011) for setting the parameters for the banking sector. The fraction of capital that can be diverted, $\kappa$, is set to 0.382 , which gives us the steady-state leverage of about $4 .^{5}$ The survival rate of bankers $\sigma$ is set to 0.97 , suggesting that the average duration for a banker to stay in business is about 8.3 years. The Calvo pricing parameter $\varepsilon$ is set to 11 , implying that the steady state markup is 10 percent.

\subsection{Priors}

We estimate six structural parameters, as well as persistence and standard deviations for the 10 exogenous shocks. The priors are displayed in Table 2. We set the priors as loose as possible, and most of them are quite standard.

The Taylor rule inflation and output coefficients, $\rho_{\pi}$ and $\rho_{y}$, are assumed to follow a gamma distribution with mean 1.5 and standard deviation 0.25 , and a normal distribution with mean 0.125 and standard deviation 0.15, respectively. We assume that the interest rate smoothing parameter $\rho_{r}$ follows a beta distribution with mean 0.8 and standard deviation 0.2 . The habit persistence parameter $b$ is assumed to fluctuate around 0.8 with a standard deviation of 0.1 , following a beta distribution. The prior on the adjustment cost parameter for business investment $\chi^{k}$ is set to follow a gamma distribution with the mean of 4 and standard deviation 1.5. For Calvo parameter $v$, we assume that it follows a beta distribution with the mean of 0.75 and standard deviation 0.1 .

The standard deviations of the innovations are assumed to follow an inverse-gamma distribution with the mean of 0.005 and two degrees of freedom. The persistence of the AR(1) processes is beta distributed with mean 0.85 and standard deviation 0.1 .

\subsection{Estimation results}

The estimation modes are presented in the last column of Table 2. The Taylor rule inflation parameters is estimated at 2.96 , and output parameter at 0.06 . This is in line with the standard result that policy rate responds mainly to inflation instead of output. The result also suggests that there is a modest degree of interest rate smoothing: $\rho_{r}=0.58$. The Calvo parameter $v$ is found to be 0.50 , suggesting that prices change every two quarters. The data also suggest that there is a significant degree of habit persistence with $b=0.85$. The investment adjustment costs parameters $\chi^{k}$ is estimated to be 10.63 , suggesting that investment adjustment is quite costly.

For the shock parameters, the investment specific shocks turn out to be the ones that have the highest volatility with $\sigma_{\epsilon^{\tau^{k}}}=0.166$. The housing demand shocks and banking sector shocks are

\footnotetext{
${ }^{5}$ As in Gertler and Karadi (2011), $\lambda$ is chosen to deliver a leverage ratio that is a compromise between the high leverage ratio for investment bank and commercial bank (20 to 40) and the low one for the corporate and non-corporate business sectors (2).
} 
also quite volatile with $\sigma_{\epsilon^{h}}=0.038$ and $\sigma_{\epsilon^{\kappa}}=0.026$, respectively. They are also quite persistent with $\rho_{h}=0.95$ and $\rho_{\kappa}=0.92$. The estimated standard deviations for the remaining parameters are ranging from 0.0015 to 0.023 .

Table 2: Estimation Results

\begin{tabular}{|c|c|c|c|c|c|}
\hline \multicolumn{2}{|r|}{ Parameter } & \multicolumn{3}{|c|}{ Prior Distribution } & \multirow[t]{2}{*}{ Posterior Mode } \\
\hline & & & \multicolumn{2}{|c|}{ Mean S.D. } & \\
\hline$\rho_{r}$ & Taylor rule smoothing & beta & 0.80 & 0.2 & 0.58 \\
\hline$\rho_{\pi}$ & Taylor rule inflation & gamm & 1.5 & 0.25 & 2.96 \\
\hline$\rho_{y}$ & Taylor rule output & norm & 0.125 & 0.15 & 0.06 \\
\hline$v$ & Calvo parameter & beta & 0.75 & 0.1 & 0.50 \\
\hline$b$ & Habit persistence & beta & 0.8 & 0.1 & 0.85 \\
\hline$\chi^{k}$ & Business investment adj. costs & gamm & 4 & 1.5 & 10.63 \\
\hline$\rho_{A}$ & Persistence, technology shock & beta & 0.85 & 0.1 & 0.73 \\
\hline$\rho_{c}$ & Persistence, consumption demand shock & beta & 0.85 & 0.1 & 0.10 \\
\hline$\rho_{h}$ & Persistence, housing demand shock & beta & 0.85 & 0.1 & 0.95 \\
\hline$\rho_{\kappa}$ & Persistence, banking sector shock & beta & 0.85 & 0.1 & 0.92 \\
\hline$\rho_{g}$ & Persistence, government shock & beta & 0.85 & 0.1 & 0.75 \\
\hline$\rho_{k}$ & Persistence, investment specific shock & beta & 0.85 & 0.1 & 0.34 \\
\hline$\rho^{y *}$ & Persistence, foreign output shock & beta & 0.85 & 0.1 & 0.85 \\
\hline$\rho^{R^{*}}$ & Persistence, foreign interest rate shock & beta & 0.85 & 0.1 & 0.74 \\
\hline$\rho^{\pi^{*}}$ & Persistence, foreign inflation shock & beta & 0.85 & 0.1 & 0.51 \\
\hline$\sigma_{\epsilon^{a}}$ & Std., technology shock & invg & 0.005 & 2 & 0.005 \\
\hline$\sigma_{\epsilon^{m}}$ & Std., monetary policy shock & invg & 0.005 & 2 & 0.003 \\
\hline$\sigma_{\epsilon^{c}}$ & Std., consumption demand shock & invg & 0.005 & 2 & 0.023 \\
\hline$\sigma_{\epsilon^{h}}$ & Std., housing demand shock & invg & 0.005 & 2 & 0.038 \\
\hline$\sigma_{\epsilon^{\kappa}}$ & Std., banking sector shock & invg & 0.005 & 2 & 0.026 \\
\hline$\sigma_{\epsilon^{g}}$ & Std., government spending shock & invg & 0.005 & 2 & 0.006 \\
\hline$\sigma_{\epsilon^{\tau^{k}}}$ & Std., investment shock & invg & 0.005 & 2 & 0.166 \\
\hline$\sigma_{\epsilon^{y *}}$ & Std., foreign output shock & invg & 0.005 & 2 & 0.0074 \\
\hline$\sigma_{\epsilon^{R *}}$ & Std., foreign interest rate shock & invg & 0.005 & 2 & 0.0015 \\
\hline$\sigma_{\epsilon^{\pi *}}$ & Std., foreign inflation shock & invg & 0.005 & 2 & 0.0017 \\
\hline \multicolumn{2}{|c|}{ Likelihood } & \multicolumn{3}{|c|}{3815.08} & \\
\hline
\end{tabular}

\section{Model Analysis}

\subsection{Model performance}

To see how the model performs, we compare the model predictions with the data in terms of means and standard deviations of the key variables in Tables 3 and 4.

Table 3 shows five key ratios in the data and their counterparts implied by the model. Table 4 compares the volatilities of the key variables in the data and the implied counterparts in the model based on the posterior modes. The reported values are normalized by the standard deviation of out- 
Table 3: Steady State: Data vs. Model

\begin{tabular}{lrr}
\hline \hline & Data & Model \\
\hline Total Consumption /GDP & $46 \%$ & $54 \%$ \\
Total housing investment/GDP & $6.35 \%$ & $6 \%$ \\
Total business investment/GDP & $17.70 \%$ & $21.80 \%$ \\
Total import/GDP & $28 \%$ & $20.50 \%$ \\
Total export/GDP & $32.10 \%$ & $18.20 \%$ \\
\hline
\end{tabular}

Table 4: Standard Deviations: Data vs. Model

\begin{tabular}{lrr}
\hline \hline & Data & Model \\
\hline Output & 1.0 & 1.0 \\
Consumption & 0.5 & 0.8 \\
Business investment & 3.2 & 4.0 \\
Housing investment & 4.5 & 5.9 \\
Mortgage loan & 5.8 & 5.0 \\
Housing prices & 1.1 & 1.8 \\
Nominal interest rate & 0.4 & 0.3 \\
Inflation & 0.1 & 0.2 \\
Risk premium & 0.2 & 0.6 \\
\hline
\end{tabular}

put. Overall the model does reasonably well in terms of matching the means. The model also does a decent job in terms of capturing the high volatilities in business investment, housing investment, mortgage loans, and housing prices, and the low volatility in consumption. For the remaining nominal variables - inflation, nominal interest rate and risk premium - the model-generated standard deviations are also close to the values in the data.

\subsection{Variance Decomposition}

Based on the estimates, we conduct variance decomposition to analyze the effect of individual shocks on the key aggregate variables, and the results are displayed in Table 5.

Table 5 shows the variance decomposition at the business cycle frequency ( 8 quarters). The results show that the fluctuations in the aggregate output for the Canadian economy are mainly driven by banking shocks (33\%), technology shocks (17\%), investment-specific shocks (16\%), and foreign interest rate shocks (13\%). Compared to the other standard shocks, the banking shocks play an important role in explaining the Canadian business cycle: in addition to output, it explains about 10 per cent of fluctuations in house prices, 19 per cent in mortgage debt, and 86 per cent in risk premium, 20 per cent in export, 40 per cent in import and 23 per cent in exchange rate. Overall, about 80 per cent of the fluctuations in mortgage debt are explained by the banking shocks and housing demand shocks. 
Table 5: Variance Decomposition

\begin{tabular}{lrrrrrrrrrr}
\hline \hline & Banking & Housing Demand & Con. Demand & Mon. Policy & Tech. & Gov. & Inv. & F. output & F. int. rate & F. inf \\
\hline Output & 33.39 & 4.91 & 3.62 & 2.57 & 17.44 & 0.97 & 16.35 & 7.44 & 13.09 & 0.21 \\
Consumption & 1.99 & 13.68 & 71.43 & 0.51 & 6.8 & 0.1 & 0.31 & 0.48 & 4.7 & 0.01 \\
Con_ip & 16.81 & 21.39 & 34.06 & 4.05 & 18.61 & 0.06 & 0.8 & 0.2 & 3.97 & 0.05 \\
Con_p & 10.26 & 1.13 & 81.58 & 1.9 & 1 & 0.08 & 0.91 & 0.58 & 2.52 & 0.02 \\
Bus. Inv. & 6.35 & 1.48 & 0.13 & 0.26 & 8.33 & 0.17 & 81.69 & 0.1 & 1.46 & 0.03 \\
Housing. Inv. & 1.76 & 95.32 & 0.04 & 0.62 & 0.21 & 0.03 & 0.91 & 0.15 & 0.96 & 0 \\
House price & 10.47 & 77.87 & 0.43 & 0.74 & 5.65 & 0.16 & 3.4 & 0.17 & 1.09 & 0.03 \\
Mortgage & 19.1 & 57.08 & 2.77 & 5.59 & 11.84 & 0.05 & 1.5 & 0.01 & 2.02 & 0.04 \\
Pol. rate & 16.96 & 2.42 & 1.17 & 9.54 & 49.14 & 0.72 & 15.26 & 0.86 & 3.61 & 0.33 \\
Inflation & 3.8 & 1.36 & 0.38 & 53.09 & 33.93 & 0.35 & 4.04 & 0.36 & 2.41 & 0.28 \\
Risk premium & 86.05 & 0.91 & 0.22 & 0.81 & 7.73 & 0.14 & 3.18 & 0.17 & 0.76 & 0.04 \\
Export & 19.8 & 1.23 & 0.22 & 0.96 & 11 & 0.19 & 2.81 & 27.55 & 35.37 & 0.87 \\
Import & 40.29 & 1.92 & 2.57 & 2.22 & 6.17 & 0.77 & 13.03 & 3.83 & 28.86 & 0.35 \\
Ex. rate & 23.39 & 1.46 & 0.29 & 1.21 & 13.85 & 0.24 & 3.6 & 12.25 & 42.52 & 1.2 \\
\hline
\end{tabular}

\subsection{Housing Demand and Banking Sector Shocks}

Given that 80 per cent of the mortgage debt fluctuations are explained by the housing demand shocks and banking shocks, in what follows we illustrate how these two shocks affect the key variables in the economy.

Figure 3 describes the impact of a banking sector shock on the aggregate economy. A decline in the fraction of assets that can be diverted by the bankers can be thought of as a decrease in riskiness in the banking sector. The reduced risk in the financial sector leads to a decline in the risk premium and a decline in the lending rate to both household borrowers (impatient households) and business borrowers. As a result, the household debt increases and consumption of the impatient households rises due to the collateral effect. Firms increase business investment and capital prices rise. Houses prices, however, decline on impact but rise gradually afterwards. This is because the rise in the policy rate increases the desire for saving by the patient households and they reduce their housing demand, leading to a decline in housing prices on impact. Overall, after a shock that reduces the riskiness of the banking sector, aggregate consumption and business investment rise, leading to an increase in aggregate output. Inflation rises, and the nominal interest rate follows it. Debt-to-GDP ratio rises although it declines on impact .

Figure 4 describes the impact of a housing demand shock on the aggregate economy. A rise in the housing demand leads to a strong rise in households debt, housing investment and housing prices. Housing affects consumption of the impatient households in two ways. 1) Collateral effect: a rise in housing demand drives up consumption. Housing demand drives up housing prices and house values, which the impatient households use as a collateral for borrowing. With the increase in the value of collateral, the impatient households consume more. 2) Substitution effect: a rise in housing demand reduces consumption demand since housing and consumption goods are substitutes in the utility function. Given these two effects, consumption and housing are positively correlated if the collateral effect dominates and negatively correlated if the substitution effect does. Figure 4 
indicates domination of the substitution effect - consumption of the impatient households declines after a positive housing demand shocks. For the patient households, the expectation of the future interest rate rise drives up deposits and as a result, both consumption and housing decline after the housing demand shock. At the aggregate level, housing investment rises since impatient households response dominates. Aggregate consumption declines since consumption of both types of households declines. Note that due to the decline in aggregate consumption, inflation decreases (although housing prices rise). The debt-to-GDP ratio rises after the shock.

\subsection{The Role of the Banking Sector}

Figure 4 also shows the role of the banking sector as a "financial accelerator" to a housing demand shock. In the baseline model, in which the banking sector is present, the lending rate (mortgage rate) declines more due to the amplification effect of the banking "financial accelerator": when households take out more loans, the bank's net worth rises and the incentive constraint is less binding. As a result, the risk premium declines, and this pushes the lending rate further down. Compared to the model without a banking sector, the rise of output in the baseline model is larger when responding to a housing demand shock. The financial accelerator effect is also present (and more pronounced) when the economy is hit by a monetary policy shock (Figure 5).

\section{Policy Experiments}

One of the key concerns about high levels of household indebtedness is that when households are highly leveraged, the impact of a sudden rise in the nominal interest rate might be devastating. The borrowers will be forced to cut back on consumption, and some of them might default on their debt, adding pressure to the banking sector. To address this issue, we consider two economies, a low debt economy with a household debt-to-GDP ratio of 0.64 , which is the average debt-to-GDP ratio from 1991Q1 to 2009Q1 for the Canadian economy; and a high debt economy with a debt-to-GDP ratio of 0.93 , the average debt-to-GDP ratio from 2009Q2 to 2015Q3. We compare the welfare gains/losses in the two economies after a sudden rise of the nominal interest rate.

Figure 6 shows the impulse responses of the key variables in the two economies to a contractionary monetary policy shock (a sudden rise in the domestic interest rate). It is clear that in the highly leveraged economy, the reduction in consumption of the impatient households is much larger. This is due to the collateral effect: when the impatient households are highly leveraged, they need to cut borrowing much more when the policy rate rises, and this leads to a larger reduction in consumption. The loss of welfare for the impatient households is larger in the high debt economy. On the other hand, the rise in interest rate benefits the patient households since they are the savers. In the high debt economy, the patient households are slightly better-off since their housing consumption and goods consumption are higher.

Figure 6, however, only sheds light on the welfare change for the impatient and patient households in response to one single shock. To evaluate the overall welfare gains/losses due to indebted- 
ness, we further assume that the two economies are subject to all the estimated shocks and compute welfare for both borrowers (impatient households) and savers (patient households) by second-order approximation. Table 6 presents the comparison across the two economies. For each economy, we report welfare in utils. We then compute the welfare changes for both borrowers and savers when they move from the high debt economy to the low debt one. Using compensating variation, we express utils in terms of steady-state consumption (in per cent). We find that the borrowers experience a welfare gain when they are less leveraged: the gain is about $0.06 \%$ of the steady-state consumption. On the other hand, the savers experience a welfare loss of about $0.04 \%$ of the steady-state consumption.

Table 6: Welfare: High Debt vs. Low Debt

\begin{tabular}{lcccc}
\hline \hline & High Debt (1) & Low Debt (2) & \multicolumn{2}{c}{ Welfare Change (2)-(1) } \\
\cline { 4 - 5 } & Utils & Utils & Utils & SS cons. (\%) \\
\hline Savers & -267.578 & -270.195 & -2.617 & -0.04 \\
Borrowers & -50.1548 & -50.1506 & 0.0042 & 0.06 \\
\hline
\end{tabular}

With this result that the welfare loss for borrowers is much larger if they are highly leveraged, let us turn to a hotly debated question of which policy tool is more suited to combat the rise in household debt. In the next section, we conduct the following policy experiments: 1) augmented monetary policy: allowing the policy rate to respond to housing prices in addition to inflation and output; 2) macroprudential policy: we consider regulatory changes in the LTV limit.

\subsection{Augmented Monetary Policy}

We define augmented monetary policy rule as follows. The central bank adjusts the nominal interest rate, $R_{t}$, in response to not only inflation and output, but also housing price inflation $\pi_{t}^{q}$ :

$$
\frac{R_{t}}{R}=\left(\frac{R_{t-1}}{R}\right)^{\rho_{r}}\left(\left(\frac{\pi_{t}}{\pi}\right)^{\rho_{\pi}}\left(\frac{y_{t}}{y}\right)^{\rho_{y}}\left(\frac{\pi_{t}^{q}}{\pi^{q}}\right)^{\rho_{q}}\right)^{1-\rho_{r}} e^{\epsilon_{t}^{m}}
$$

where $\rho_{q}>0$, and $\pi^{q}$ is the steady-state housing price inflation.

Figure 7 compares the impulse response functions across the two regimes: the baseline with the estimated monetary policy rule and the augmented regime in which the policy rate responds to housing price inflation, with $\rho_{q}=1$. In response to a positive housing demand shock, household debt rises under both regimes, but less so under the augmented regime. This is because in the augmented regime, the policy rate rises in reaction to housing prices. The rise in policy rate reduces borrowing from both households and businesses. With the banking sector financial accelerator mechanism, the mortgage rate rises even further. As a result, output in the augmented regime rises significantly less than in the baseline model. Moreover, inflation declines much more than in the baseline model. Overall, consumption and housing stock of the impatient households decline; they have to work 
more and their overall welfare declines. The patient households, however, benefit from the rise in interest rates - they deposit more and work less, and their overall welfare rises slightly.

Next we conduct a stochastic simulation to compute welfare under the two regimes in the presence of all the shocks considered in the model. Table 7 presents the welfare comparison between the baseline model and augmented regime with $\rho_{q}$ ranging from 1 to 3 . It shows that when policy rate reacts more strongly to housing prices, welfare of impatient households decreases while that of patient households increases. Moreover, under the augmented regime inflation volatility increases more when the policy rate responds more aggressively to housing prices.

Table 7: Welfare: Baseline vs. Augmented

\begin{tabular}{lccc}
\hline \hline & \multicolumn{2}{c}{ Welfare } & Inflation Volatility \\
& Savers & Borrowers & (SD) \\
\hline Baseline & -267.5776 & -50.1548 & 0.0026 \\
Aug. rule $\rho_{q}=1$ & -267.5687 & -50.1572 & 0.0038 \\
Aug. rule $\rho_{q}=2$ & -267.4894 & -50.1683 & 0.0058 \\
Aug. rule $\rho_{q}=3$ & -267.3397 & -50.1871 & 0.0081 \\
\hline
\end{tabular}

\subsection{Macroprudential Policy - Tightening LTV}

From 2008 to 2012, the Canadian government tightened its lending standard: the LTV limit for new mortgages was lowered from $100 \%$ to $95 \%$, the LTV limit for mortgage refinancing lowered from $95 \%$ to $80 \%$, the LTV limit for investment properties lowered from $95 \%$ to $80 \%$, and the maximum amortization period shortened from 40 years to 25 years. In this section, we use our model to explore the effect of permanently tightening the LTV limit. We consider two economies. In one economy the LTV ratio is $62.5 \%$, corresponding to a debt-to-GDP ratio of 0.93 , which was the average debtto-GDP ratio for the period from 2009Q2 to 2015Q3. The other economy's LTV ratio is $15 \%$ lower. We chose $15 \%$ because it is a good proxy for the policy changes mentioned above.

Table 8: Welfare: LTV Reform

\begin{tabular}{llllc}
\hline \hline & Before tightening (1) & \multicolumn{2}{c}{ After tightening (2) } & \multicolumn{2}{c}{ Welfare change (2)-(1) } \\
\cline { 3 - 5 } & \multicolumn{1}{c}{ Utils } & Utils & Utils & SS cons (\%) \\
\hline Savers & -267.58 & -269.19 & -1.61 & -0.034 \\
Borrowers & -50.1548 & -50.1409 & 0.0139 & 0.04 \\
\hline
\end{tabular}

We use a second-order approximation to welfare as well as compensating variation to transform utils to steady-state consumption. Table 8 shows that the borrowers are better off after the tightening, and the gain is about $0.04 \%$ of the steady-state consumption. On the other hand, the welfare of the savers is lower due to the new LTV limit, the welfare loss being about $0.034 \%$ of the steady-state consumption. 


\section{Conclusions}

In this paper, we develop a small open economy DSGE model featuring two types of households with heterogeneous desires for saving and borrowing. We estimate the model using the Canadian data and based on the estimates, we compare two types of policy and evaluate their suitability for reducing household indebtedness. We find that housing demand shocks are the main shocks contributing to household debt dynamics. We also find that in response to a positive housing demand shock, housing prices rise while inflation declines, and this leads to one of our key results - using monetary policy that reacts to household indebtedness will increase inflation volatility, and in turn decrease the borrowers' welfare. Our results suggest that using macroprudential policy tools such as lowering LTV limits is a better alternative.

Unlike the majority of the literature on the relationship between household debt and monetary policy, the banking sector frictions in our model are explicitly modeled, and this allows us to identify the role of the banking sector in explaining household debt dynamics. One possible avenue for our future research would be to evaluate the role of banking sector regulations on reducing household debt.

We view the welfare losses/gains for borrowers in the model as a lower bound as we have not explicitly modeled bankruptcy and foreclosure and their impact on borrowers and the banking sector. Welfare analysis that includes these new features could be another direction of our future research. 


\section{Appendix 1. Data Construction}

The model is estimated with Canadian quarterly data from 1991Q1 to 2015Q3. We use the following time series as observables. All the real variables are logged and de-trended by a HP filter.

1. Output

Model variable: $y_{t}$

Data source: Statistic Canada, Cansim, Table 380-0064, Gross domestic product, expenditurebased, quarterly (dollars x 1,000,000). Normalized by civilian population.

2. Consumption

Model: $c_{t}$

Data: includes households' consumption on nondurable consumption goods, semi-durable goods and services. Data source: Cansim, Table 380-0064. It is normalized by civilian population.

3. Business investment

Model variable: $i_{t}^{k}$

Data: includes durable consumption goods and business gross fixed capital formation (minus residential structure). Data source: Cansim, Table 380-0064. Normalized by civilian population.

4. Housing investment

Model variable: $i_{t}^{h}$

Data: investment on residential structure. Data source: Cansim, Table 380-0064. Normalized by civilian population.

5. Government spending

Model variable: $g_{t}$

Data: General governments final consumption expenditure. Source: Cansim, Table 380-0064. Normalized by civilian population.

6. Mortgage debt

Model variable: $\ell_{t}$

Data: Residential mortgage debt outstanding insured and uninsured. Source: Cansim, Table 176-0014. Normalized by civilian population and GDP deflator.

7. House prices

Model variable: $q_{t}$

Data: New housing price index. Source: Cansim, Table 327-0046, New housing price index, monthly (index, 2007=100). 
8. Risk premium

Model variable: $s_{t}$

Data: The difference between 3-month treasury bill and 5-year term conventional mortgage lending rate. Data source for 5-year term conventional mortgage lending rate: Cansim, Table 027-0015.

9. Nominal interest rate

Model variable: $R_{t}$

Data: Rates on 3-month treasury bills. Source: Cansim, Table 176-0043 Financial market statistics.

10. Inflation

Model variable: $\pi_{t}$

Data: Calculated by using the Bank of Canada's core CPI. Data source: Table 326-0022

Consumer Price Index, seasonally adjusted, quarterly $(2002=100)$. 


\section{References}

Alpanda, S. and Ueberfeldt, A. (2016). Should monetary policy lean against housing market booms? Bank of Canada Staff Working Paper 2016-19.

Alpanda, S. and Zubairy, S. (2017). Addressing household indebtedness: Monetary, fiscal or macroprudential policy? European Economic Review, 92: 47-73.

Bruneau, G., Christensen, I., and Meh, C. A. (2016). Housing market dynamics and macroprudential policy. Bank of Canada Staff Working Paper 2016-31.

Calvo, G. A. (1983). Staggered prices in a utility-maximizing framework. Journal of Monetary Economics, 12(3): 383-398.

Chen, M. J. and Columba, M. F. (2016). Macroprudential and monetary policy interactions in a DSGE model for Sweden. IMF Working Paper 16/74.

Christensen, I., Corrigan, P., Mendicino, C., and Nishiyama, S.-I. (2016). Consumption, housing collateral and the Canadian business cycle. Canadian Journal of Economics, 49(1): 207-236.

Christiano, L. J., Eichenbaum, M., and Evans, C. L. (2005). Nominal rigidities and the dynamic effects of a shock to monetary policy. Journal of Political Economy, 113(1): 1-45.

Gerali, A., Neri, S., Sessa, L., and Signoretti, F. M. (2010). Credit and banking in a DSGE model of the euro area. Journal of Money, Credit and Banking, 42(s1): 107-141.

Gertler, M. and Karadi, P. (2011). A model of unconventional monetary policy. Journal of Monetary Economics, 58(1): 17-34.

Gertler, M. and Kiyotaki, N. (2015). Banking, liquidity and bank runs in an infinite-horizon economy. American Economic Review, 105(7): 2011-43.

Hall, R. E. (2011). The long slump. American Economic Review, 101(2): 431-469.

Iacoviello, M. (2005). House prices, borrowing constraints, and monetary policy in the business cycle. American Economic Review, 95(3): 739-764.

Iacoviello, M. (2015). Financial business cycles. Review of Economic Dynamics, 70: 22-38.

Justiniano, A., Primiceri, G. E., and Tambalotti, A. (2013). Household leveraging and deleveraging. Review of Economic Dynamics, 18(1): 3-20.

Kiyotaki, N. and Moore, J. (1997). Credit cycles. Journal of Political Economy, 105(2): 211-248.

Li, W. and White, M. J. (2009). Mortgage default, foreclosure, and bankruptcy. NBER Working Paper 15472. 
Meh, C. A. and Moran, K. (2010). The role of bank capital in the propagation of shocks. Journal of Economic Dynamics and Control, 34(3): 555-576.

Neri, S. and Iacoviello, M. (2010). Housing market spillovers: Evidence from an estimated DSGE model. American Economic Journal: Macroeconomics, 2(2): 125-164.

Schmitt-Grohé, S. and Uribe, M. (2003). Closing small open economy models. Journal of International Economics, 61(1): 163-185.

Zhang, Y. (2015). Household debt, financial intermediation, and monetary policy. University of Windsor Working Paper 15-04. 
Figure 2: Detrended Data Used in Estimation
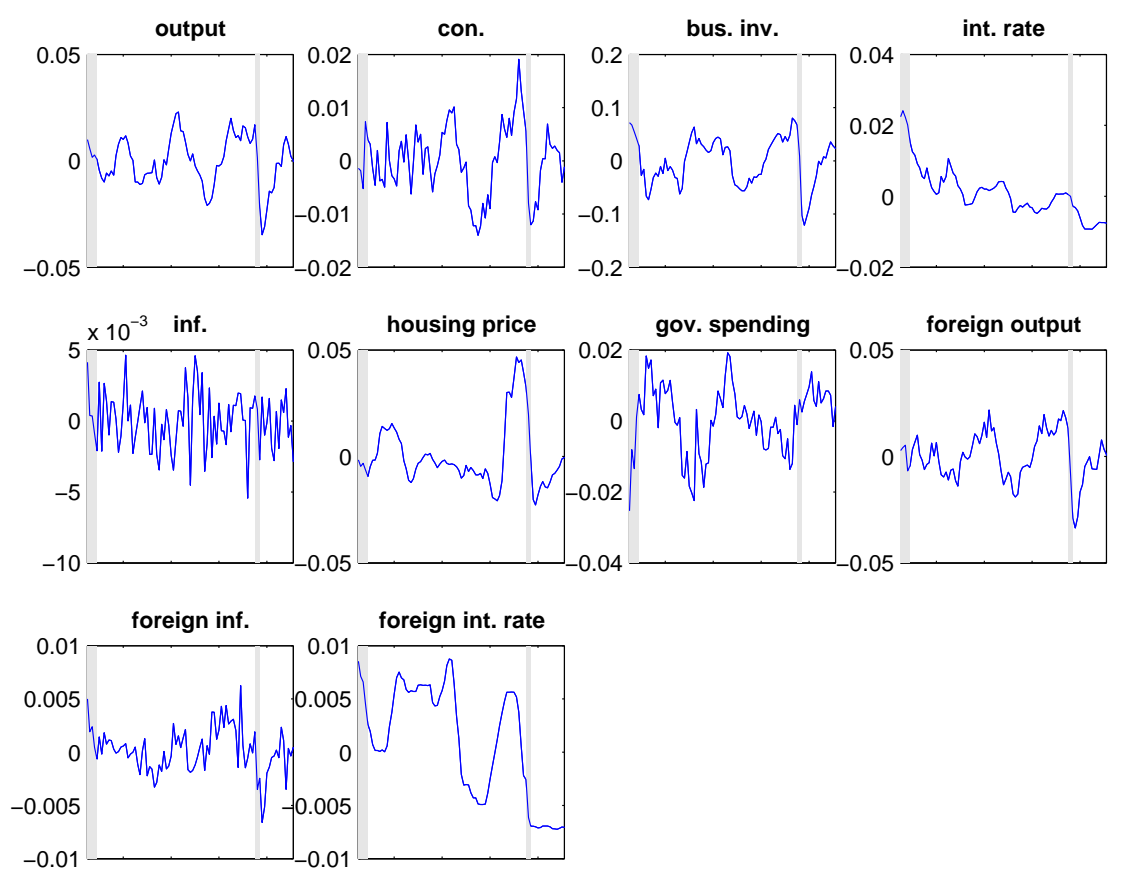

All the real variables are in percentage deviations from the their trends and all the nominal variables are in percentage deviations from their means. 
Figure 3: Effects of a Banking Sector Shock

\section{Dynamic Responses to a Banking Shock: Baseline}

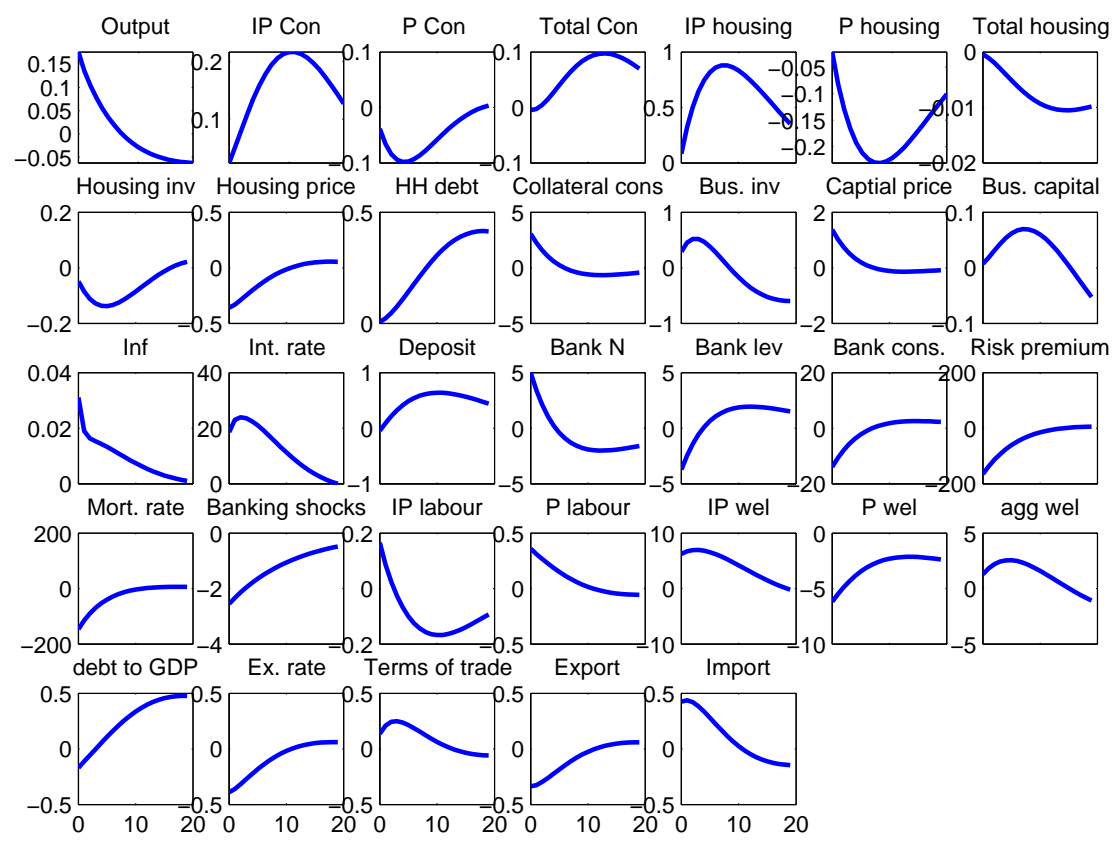

All the variables are in percentage deviations from their steady-state values except interest rate, risk premium and mortgage rate which are in basis points. IP denotes the impatient households. $\mathrm{P}$ denotes patient households. Further clarifications regarding some of the notations: IP con: consumption of the impatient households, P Con: consumption of the patient households, Total con: total consumption, Collateral cons: collateral constraint, Bus. inv: business investment, inf: inflation, int. rate: interest rate, Bank N: bank net worth, Bank lev: bank leverage, Bank cons: bank incentive constraint, Mort. rate: mortgage rate, IP wel: welfare of the impatient households, $\mathrm{P}$ wel: welfare of the patient households, agg wel: aggregate welfare, and Ex. rate: exchange rate. 
Figure 4: Effects of a Housing Demand Shock: Baseline vs. NoBank

\section{Dynamic Responses to a Housing Demand Shock: Baseline vs Nobank}
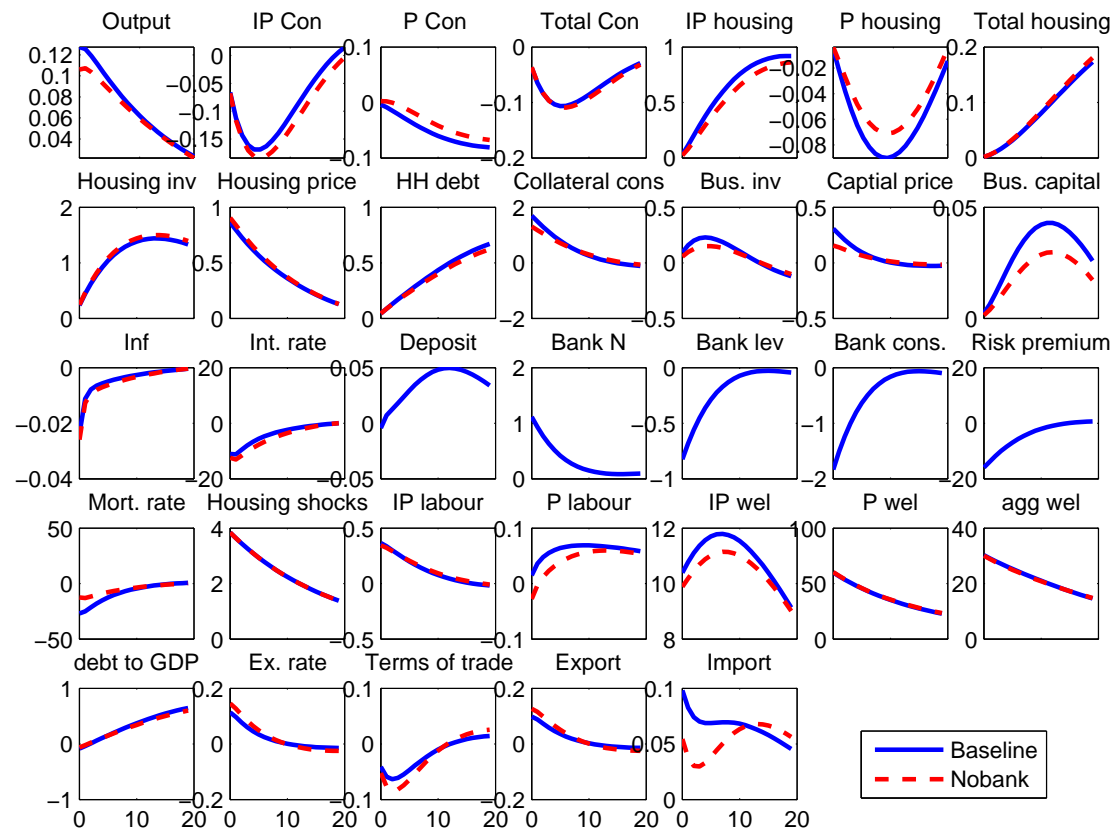

- - Nobank

All the variables are in percentage deviations from their steady-state values except interest rate, risk premium and mortgage rate which are in basis points. IP denotes the impatient households. P denotes patient households. Further clarifications regarding some of the notations: IP con: consumption of the impatient households, P Con: consumption of the patient households, Total con: total consumption, Collateral cons: collateral constraint, Bus. inv: business investment, inf: inflation, int. rate: interest rate, Bank N: bank net worth, Bank lev: bank leverage, Bank cons: bank incentive constraint, Mort. rate: mortgage rate, IP wel: welfare of the impatient households, $\mathrm{P}$ wel: welfare of the patient households, agg wel: aggregate welfare, and Ex. rate: exchange rate. 
Figure 5: Effects of a Monetary Policy Shock: Baseline vs. NoBank

\section{Dynamic Responses to a Monetary Policy Shock: Baseline vs Nobank}

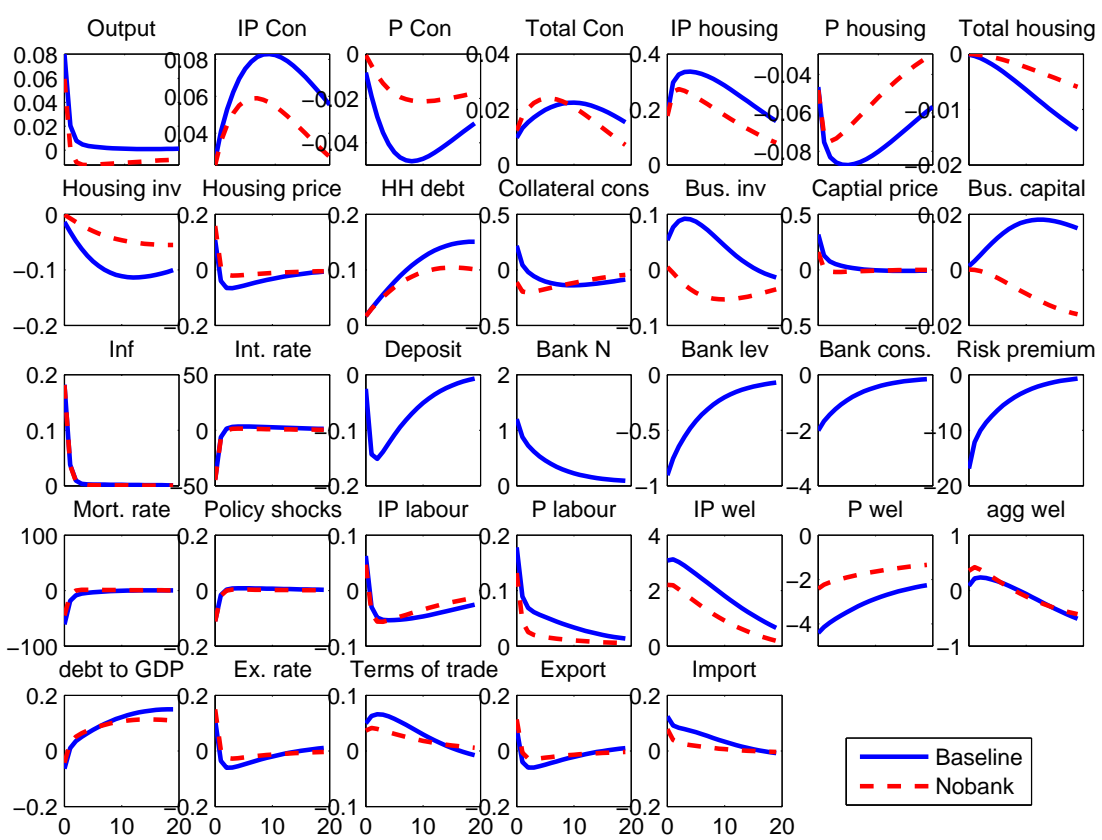

All the variables are in percentage deviations from their steady-state values except interest rate, risk premium and mortgage rate which are in basis points. IP denotes the impatient households. $\mathrm{P}$ denotes patient households. Further clarifications regarding some of the notations: IP con: consumption of the impatient households, P Con: consumption of the patient households, Total con: total consumption, Collateral cons: collateral constraint, Bus. inv: business investment, inf: inflation, int. rate: interest rate, Bank N: bank net worth, Bank lev: bank leverage, Bank cons: bank incentive constraint, Mort. rate: mortgage rate, IP wel: welfare of the impatient households, $\mathrm{P}$ wel: welfare of the patient households, agg wel: aggregate welfare, and Ex. rate: exchange rate. 
Figure 6: Effect of a Contractionary Domestic Interest Rate Shock: High vs. Low Leverage

\section{Dynamic Responses to a Monetary Policy Shock}

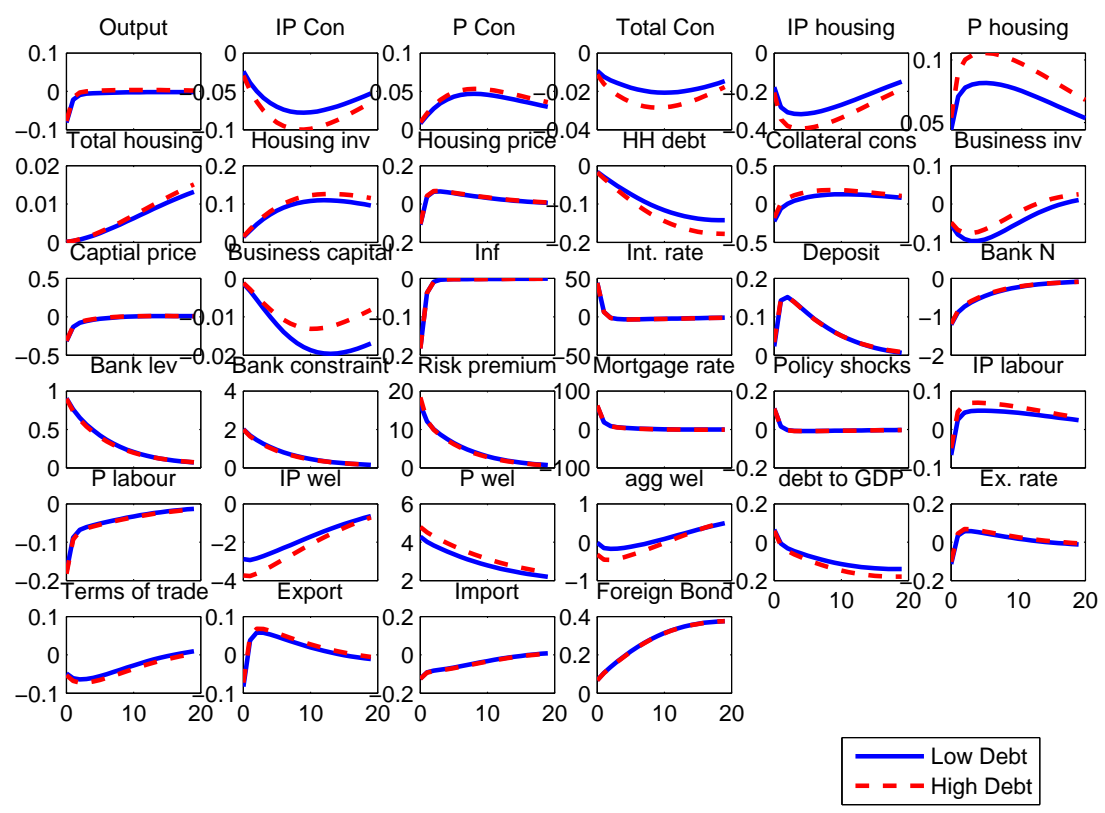

All the variables are in percentage deviations from their steady-state values except interest rate, risk premium and mortgage rate which are in basis points. IP denotes the impatient households. P denotes patient households. Further clarifications regarding some of the notations: IP con: consumption of the impatient households, P Con: consumption of the patient households, Total con: total consumption, Collateral cons: collateral constraint, Bus. inv: business investment, inf: inflation, int. rate: interest rate, Bank N: bank net worth, Bank lev: bank leverage, Bank constraint: bank incentive constraint, Mort. rate: mortgage rate, IP wel: welfare of the impatient households, $\mathrm{P}$ wel: welfare of the patient households, agg wel: aggregate welfare, and Ex. rate: exchange rate. 
Figure 7: Effect of a Positive Housing Demand Shock: Baseline vs. Policy

Dynamic Responses to a Housing Shock

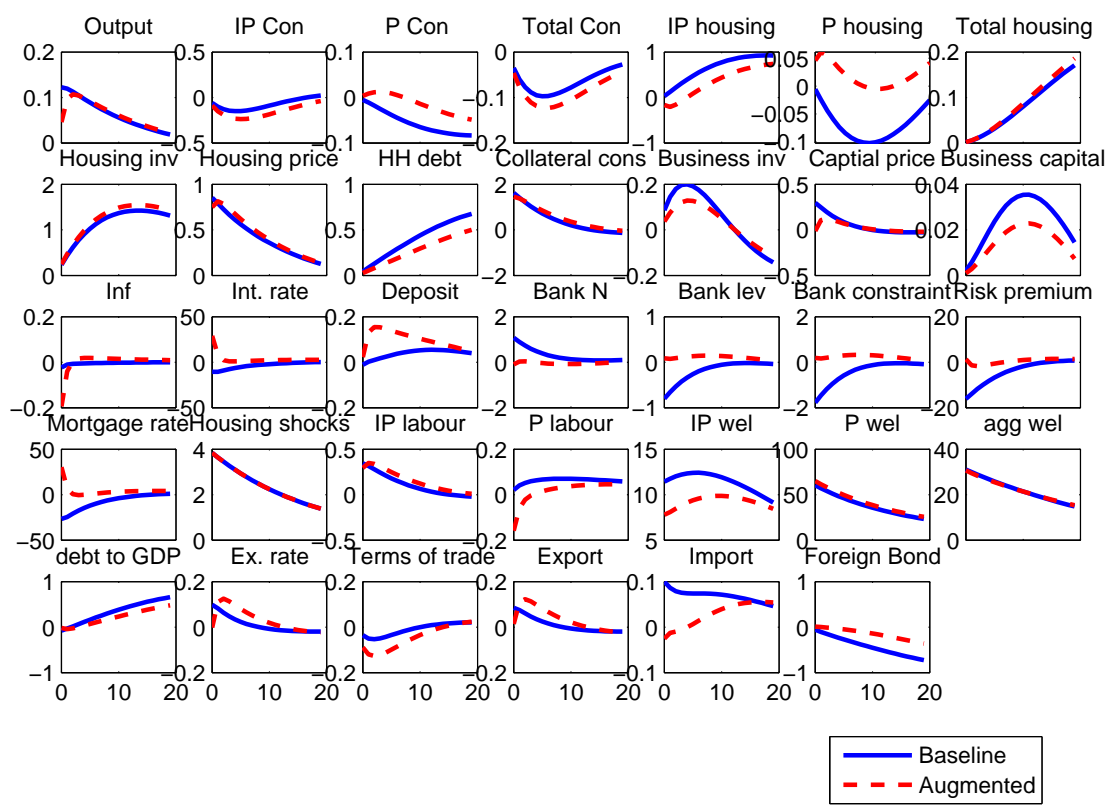

All the variables are in percentage deviations from their steady-state values except interest rate, risk premium and mortgage rate which are in basis points. IP denotes the impatient households. P denotes patient households. Further clarifications regarding some of the notations: IP con: consumption of the impatient households, P Con: consumption of the patient households, Total con: total consumption, Collateral cons: collateral constraint, Bus. inv: business investment, inf: inflation, int. rate: interest rate, Bank N: bank net worth, Bank lev: bank leverage, Bank constraint: bank incentive constraint, Mort. rate: mortgage rate, IP wel: welfare of the impatient households, $\mathrm{P}$ wel: welfare of the patient households, agg wel: aggregate welfare, and Ex. rate: exchange rate. 